\title{
Blue-green algae in surface water: problems and opportunities
}

2

3 Hang P. Vu ${ }^{1}$, Luong N. Nguyen ${ }^{1 *}$, Jakub Zdarta ${ }^{2}$, Tran T.V. Nga ${ }^{3}$, and Long D. Nghiem ${ }^{1,4}$ 4

5

6

7

$8{ }^{1}$ Centre for Technology in Water and Wastewater, University of Technology Sydney, Ultimo 9

$20{ }^{*}$ Corresponding author:

21 Luong N. Nguyen: Centre for Technology in Water and Wastewater, School of Civil and

22 Environmental Engineering, University of Technology Sydney, NSW 2007, Australia

23 Phone: (+61) 468863865 E-mail: luongngoc.nguyen@uts.edu.au

\section{Accepted Manuscript}

\section{Current Pollution Report}

NSW 2007, Australia

${ }^{2}$ Institute of Chemical Technology and Engineering, Faculty of Chemical Technology, Poznan University of Technology, Berdychowo 4, PL-60965 Poznan, Poland

${ }^{3}$ Faculty of Environmental Engineering, Hanoi University of Civil Engineering ${ }^{4}$ NTT Institute of Hi-Technology, Nguyen Tat Thanh University, Ho Chi Minh City, Vietnam 


\section{Abstract}

Cyanobacteria, commonly known as blue-green algae, are often seen as a problem. Their accumulation (bloom) in surface water can cause toxicity and aesthetic concerns. Efforts have

28 been made in preventing and managing cyanobacterial blooms. By contrast, purposeful cultivation of cyanobacteria can create great opportunities in food, chemical and biofuel applications. This review summarises the current stage of research and the socio-economic impacts associated with both the problems and opportunities induced from the presence of cyanobacteria in surface water.

\section{Recent Findings}

Insightful knowledge of factors that trigger cyanobacterial blooms has allowed for the development of prevention and control strategies. Advanced technologies are utilised to detect, quantify and treat cyanobacterial biomass and cyanotoxins in a timely manner. Additionally, understanding of cyanobacterial biochemical properties enables their applications in food and health industry, agriculture and biofuel production. Researchers have been able to genetically modify several cyanobacterial strains to obtain a direct pathway for ethanol and hydrogen production.

Summary

Cyanobacterial blooms have been effectively addressed with advances technologies and cyanobacterial research. However, this review identified a knowledge gap regarding cyanotoxin synthesis and the relevant environmental triggers. This information is essential for developing measures to prevent cyanobacterial blooms. Additionally, this review affirms the promising opportunities that cyanobacteria offer in the food, cosmetics, pigments and agriculture. Biofuel production from cyanobacterial biomass presents an immense potential but is currently constrained by the cultivation process. Thus, future research should strive to achieve effective mass harvesting of cyanobacterial biomass and obtain a profound understanding of cyanotoxin production.

51 Keywords: Cyanobacteria; Cyanotoxins; Cyanobacterial bloom; Biofuels; Cyanobacterial bloom impacts 
Cyanobacteria are a type of photosynthetic green-looking or blueish bacteria [1]. They possess chlorophyll $a$ and release oxygen as a product of photosynthesis. The green pigment chlorophyll $a$ together with other accessory pigments often cause a masking effect on the cyan (blue-green) hue of cyanobacterial pigment phycocyanin [2]. Cyanobacteria possess the oldest known fossils, dated back to 3.5 billion years ago. They have a significant contribution to the evolution and ecological change throughout the earth's history [3].

Harmful cyanobacterial blooms are a global problem. Found in a range of water environments (freshwater, coastal and marine), they have bloom-forming capabilities which pose significant concerns to the community. Cyanobacterial blooms are a threat to the drinking water supply due to their potential toxicity and the release of taste and odour compounds (e.g. Geosmin and 2-Methyl-Isoborneol). Cyanotoxins produced from several common cyanobacteria are extreme risks to public health. Human or wildlife exposure to cyanotoxins can lead to severe illness, including death [4-6]. Additionally, harmful cyanobacterial blooms incur significant damage to the economy by disrupting the tourism and agricultural industry. Millions of dollars are spent every year to manage and control the impacts of cyanobacterial blooms [7].

New tools and technologies have been developed for managing cyanobacteria in surface water. For example, smart satellite imaging technique allows for early detection of cyanobacterial blooms [8]. Data collected from this system enables the authorities to develop real-time cyanobacterial bloom alerts useful for the general public and water suppliers. Types of cyanobacteria species and cyanotoxins can then be identified and possibly quantified from several approaches such as genetic techniques (e.g. quantitative polymerase chain reaction), biochemical assays and liquid chromatography $[9,10]$.

Apart from those aforementioned problems, cyanobacteria and their biomass also present great opportunities for the production of sustainable and valuable commodities. Cyanobacteria (e.g. Spirulina) are rich in proteins, vitamins and bioactive compounds [11]. Some cyanobacteria and their products are thus suitable to be consumed as food or health supplement. Useful bioactive compounds extracted from cyanobacteria were also shown to have natural antioxidant and water retention properties [12]. These make them great replacements for synthetic compounds often used in cosmetic formulations. Some cyanobacteria are capable of nitrogen-fixing, thus, cyanobacterial biomass from these species can be used as biofertilisers 
and soil conditioners [13]. Cyanobacterial biomass has also been actively explored as a potential feedstock to produce biofuels. Several studies have reported the production of ethanol, isobutanol and clean hydrogen from engineered cyanobacterial strains [14-16].

Global warming is likely to exacerbate harmful cyanobacterial bloom in both intensity and frequency [2]. The result can be both a threat of severe consequences of harmful cyanobacterial blooms and an opportunity to utilise them for beneficial applications. Several independent studies have underlined the problems or benefits of cyanobacteria and corresponding management strategies [2, 17-19]. Each of them was able to deliver useful and novel insights on a particular aspect of the topic. However, a complete overview on cyanobacteria in surface water and its impacts is inadequate. This paper aims to provide a full perspective of the topic, highlighting the current problems and opportunities associated with cyanobacteria in surface water, as well as the technologies used for cyanobacterial detection, control and harvesting. The knowledge gaps regarding cyanobacterial properties, cyanotoxins production and harvesting methods are also delineated through reviewing recent publications. This information is useful for the effective management of cyanobacteria and converting cyanobacterial biomass into valuable products.

\section{Cyanobacteria}

\subsection{Cyanobacterial classification and phenotype}

Cyanobacteria are photosynthetic prokaryotes which can grow in fresh, brackish and seawater [20]. There are about 2,000 cyanobacterial species in 150 genera [21] such as Chroococcales, Anabaena, and Nodularia. Cyanobacterial cells are identified to be more elaborated and larger than regular bacteria ( 0.5 to $60 \mu \mathrm{m}$ in diameter). They are commonly found in unicellular, colonial and filamentous forms (Fig. 1) [22]. Their photosynthetic features and oxygen production set them apart from other bacteria. Several accessory pigments (e.g. chlorophyll a, phycocyanin and allophycocyanin) in the cells are light-harvesting antennae that capture the sunlight for energy in cyanobacterial photosynthesis. 


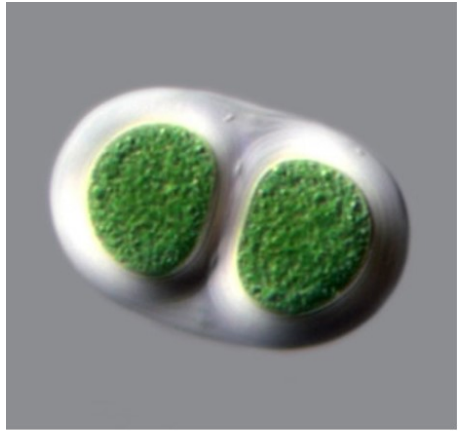

Chroococcales (unicellular)

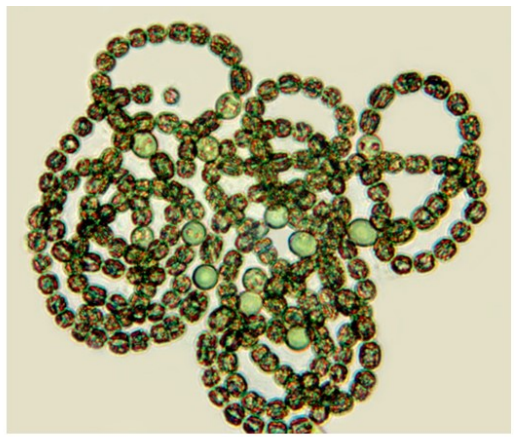

Anabaena (filamentous)

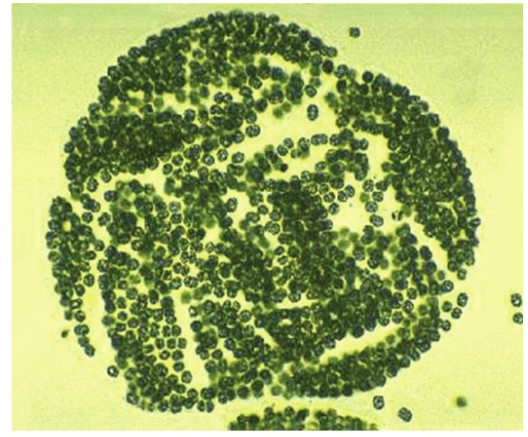

Microcystis (colonial)

113 Figure 1: The three common morphologies of cyanobacteria. Image courtesy of Landcare

Research [23]

115

116

117

118

119

120

121

122

123

124

125

126

127

128

129

130

131

132

133

134

135

Most surface water cyanobacteria species have cells that contain gas vacuoles consisting of multiple gas vesicles. These gas vacuoles give cyanobacteria the buoyancy ability i.e. the ability to remain in suspension and float to the water surface [24]. In highly stratified water or waters with great fluctuations in vertical mixing and optical depth, cyanobacteria with buoyancy-assisted vertical movements are favoured [25]. They are able to float to the water surface for optimal nutrients and light availability. Thus, their bloom forming capacity is enhanced and causes difficulty in removing cyanobacteria biomass from water (Section 4.3).

Cyanobacteria possess $\mathrm{CO}_{2}$-concentrating mechanisms $(\mathrm{CCMs})$ which consist of five inorganic carbon uptake systems. These enable the cells to increase the $\mathrm{CO}_{2}$ substrate for photosynthesis as well as the $\mathrm{CO}_{2}$ concentration in the cellular micro-compartments for efficient enzyme operation [2]. The use of cyanobacteria for $\mathrm{CO}_{2}$ sequestration has been found to be very effective due to the presence of these CCMs [26, 27].

Another notable phenotype of many cyanobacteria is to fix atmospheric nitrogens (e.g. nitrogen-fixing cyanobacteria includes Anabaena, Nostoc and Nodularia). Their cell structures (i.e. heterocyst) are thick wall which is impermeable to oxygen but permeable to nitrogen [28]. Nitrogen fixation is a competitive advantage for these filamentous cyanobacteria in a nitrogenlimited environment.

\subsection{Cyanobacterial bloom triggers}

Cyanobacterial blooms are the result of rapid and excessive growth as well as accumulation of cyanobacterial biomass on the water surface [2]. Because of the photosynthetic activity, environmental conditions include nutrient availability, temperature, light exposure and $\mathrm{CO}_{2}$ are 
136 key factors to cyanobacterial growth $[29,30]$. When these conditions are combined (e.g. often 137 in summertime), cyanobacterial blooms will occur. Common harmful bloom-forming genera 138 are Aphanizomenon, Cylindrospermopsis, Dolichospermum, Microcystis, Nodularia, 139 Planktothrix and Trichodesmium [2].

140 Significant research efforts have been devoted to exploring the optimal growth conditions 141 of cyanobacteria, which lead to blooms [31]. These conditions provide intuitive information to prevent and control cyanobacterial blooms (Section 4). For example, the eutrophic condition with low nitrogen to phosphorous ratio ranging from 10 to 15 is suggested to be optimal for cyanobacterial growth [22]. Literature data also indicates that phosphorus-rich water supports the dominance of cyanobacteria over other phytoplankton communities [32-34]. Smith (1983) hypothesised that by modifying the total nitrogen to total phosphorous ratio, cyanobacterial growth could be controlled [29]. This is due to the low count of cyanobacteria at nitrogen phosphorous ratio greater than 29 to 1 by weight [29]. Light exposure (i.e. light intensity and duration) is another significant factor in determining the formation and duration of blooms [35]. Cyanobacteria contain a range of pigments such as chlorophyll $a$, allophycocyanin and phycocyanin which harvest light in the green, yellow and orange part of the spectrum. This range is much wider than that used by other phytoplankton species, giving cyanobacteria an advantage in terms of absorbing light for photosynthesis [22]. However, Montechiaro F. and Giordano M. (2006) had reported that some cyanobacteria (e.g. Phormidium autumnale) can hypernate without virtually any light for months and are able to thrive immediately following light exposure [36]. This emphasises the specific response and flexibility of individual cyanobacteria to light exposure. Water temperature $\left(25^{\circ} \mathrm{C}\right.$ or above $)$ is also favourable for cyanobacterial growth, thus more severe blooms are observed in late spring throughout summer. In recent years, cyanobacterial blooms appear to occur earlier and last longer possibly as the result of climate change. Warm temperature reduces water viscosity, thus stimulating the sedimentation of competing larger, non-motile phytoplankton with weak floating ability [31]. O'Niel et. al. [31] suggest that cyanobacteria have better competitiveness when stratification of water body occurs due to insular heating. The warmer upper water layer is more abundant in nutrients and light during stratification. Cyanobacteria can float upwards and utilise these factors for more rapid reproduction.

166 Rising atmospheric $\mathrm{CO}_{2}$ due to global warming also contributes to the severity of cyanobacterial blooms $[2,37]$. It forms a steeper concentration gradient with the dissolved $\mathrm{CO}_{2}$, which has been depleted by cyanobacterial development. This leads to a greater influx of $\mathrm{CO}_{2}$ 
169 into the water body to reach equilibrium with the atmosphere [37]. Higher dissolved $\mathrm{CO}_{2}$ 170 concentration intensifies bloom formation. Besides, the $\mathrm{CO}_{2}$ - concentrating mechanism 171 (CCMs) can utilise this availability of $\mathrm{CO}_{2}$ to enhance the function and growth of 172 cyanobacteria.

173 Other factors influencing cyanobacterial blooms include water stratification and wind patterns $[38,39]$. Stagnant water condition allows for a longer residence time of cyanobacterial cells. As a result, more nutrients, light radiation and $\mathrm{CO}_{2}$ are absorbed, increasing cyanobacterial growth rate. Light winds can expand the area of cyanobacterial scums [39] by driving them closer together and towards shores and bays. This increases the chances of human or animal in contact with the blooms which may contain harmful cyanotoxins. Awareness of such potential toxicity and measures for prevention and control of cyanobacterial blooms to be put in place are extremely important for the community.

\section{Impact of cyanobacterial blooms}

\subsection{Cyanotoxin production and its consequences}

Cyanotoxins are secondary products (metabolites) from the metabolism of several cyanobacteria, most commonly Microcystis, Anabaena and Planktothrix genera [40-42]. They possess a variety of biological structures and induce a range of negative effects on human and animal health (Table 1). Cyanotoxins are usually produced and contained within the cyanobacterial cells (intracellular) [41]. Environmental stress or chemical and mechanical processes applied to cyanobacterial bloom can cause cell death, stimulating the release of cyanotoxins into the waterbody (extracellular). Benthic cyanobacteria such as Nostoc and Lyngbia do not occupy surface water but their occurrence and release of extracellular cyanotoxins into the surrounding water contribute to the harmful impacts of cyanobacterial blooms.

There are three main groups of cyanotoxins based on their chemical structure including cyclic peptides (e.g. microcystins and nodularins), alkaloids (e.g. neurotoxins and cylindrospermopsin) and lipopolysaccharides [4]. Cyanotoxins may also be classified into

196 three groups according to their toxic effects: hepatotoxins, neurotoxins and dermototoxins

197 (Table 1). Microcystins and nodularins are hepatotoxic cyclic peptides containing specific 198 amino acids such as Adda (2S, 3S, 8S, 9S)-3-amino-9-methoxy-2, 6, 8-trimethyl1-10pheny1deca-4, 6-dienoic acid) [2]. Microcystins and nodularins inhibit the function of protein 
phosphatases, resulting in severe liver damage in human $[2,4]$. Other health impacts could involve kidney and colon malfunctions, gastroenteritis, allergic and irritation reactions [42].

The alkaloid cyanotoxins include cylindrospermopsin, saxitoxins and anatoxins [4, 43, 44]. Cylindrospermopsin is a well-known hepatotoxin with the primary target of toxic effects being liver and kidney. Saxitoxins are representative neurotoxins of a large toxin family responsible for paralytic shellfish poisoning [45]. Saxitoxins are among the most potent toxins known. They can cause rapid paralysis by impairing the neuron systems and inhibiting muscle contraction [46]. Similarly, anatoxins and its variants anatoxin-a, anatoxin-a(s) are neurotoxins affecting the central nervous system. They can cause paralysis and asphyxiation (being oxygendeprived) [47, 40]. Aplysiatoxins and lyngbyatoxin are representative of the dermatotoxin alkaloids. They can cause inflammation and severe dermatitis to people in contact with the filaments. These toxins are found in marine blue-green algae such as Planktothrix and Oscillatoria [48, 49]. They are potent tumour promoters and protein kinase C activators [50]. Lipopolysaccharides is the last group of cyanotoxins classified by chemical structure.

214 Lipopolysaccharides helps to determine and maintain the shape and size of the cell [48].

215 Lipopolysaccharides trigger irritant and allergenic responses in mammals and tissues in contact 216 with the toxins. They pose a significant concern for exposure due to their universal presence 217 on the cell wall of a wide variety of cyanobacteria [4].

218 The distribution of cyanobacteria and cyanotoxins varies temporally and spatially. This 219 could be due to the variations in the characteristics of cyanobacterial species and their preferred 220 blooming conditions. Tropical Africa and Asia are abundant in bloom-forming genus 221 Microcystis while Cylindrospermopsis is the most prevalent in Australia [17]. Both of these genera have occurred frequently in tropical America. As a result, there are differences in the cyanotoxins presented in these areas. The most common toxins in general are microcystis [41]. Cylindrospermopsin is the most frequently encountered cyanotoxin in Australia and anatoxin is commonly found in Africa produced by blooms of Anabaena species [17].

Evidence on chronic health effects caused by exposure to recreational water infected with cyanobacterial bloom has been well documented in many parts of the world [4]. In the Paulo Afonso region of Brazil's Bahia State, there were 2,000 reported cases of gastroenteritis and 88 deaths over a period of 42 days in 1988. This was the result of Anabaena and Microcystis blooms in the newly constructed Itaparica Dam's reservoir [6]. Lake Taihu, the third-largest freshwater lake in China supplying water for potable use has also long been infected with 
232 harmful cyanobacterial blooms [5]. The presence of high concentration microcystin toxin from 233 Microcystis spp. in untreated water $(4.8-44.00 \mu \mathrm{g} / \mathrm{L})$ in Lake Taihu have impaired the drinking 234 water supplies. This concentration is higher than the upper limit of safe value for human 235 exposure recommended by WHO $(1 \mu \mathrm{g} / \mathrm{L})($ Table 1$)$. Toxin residue was also detected in the 236 treated tap water, which has been suggested to contribute to the prevalence of liver cancer in 237 cities along Lake Taihu [51].

238 Concentration of cyanotoxins detected in a cyanobacterial bloom event is unpredictable and 239 often exceeds the drinking water guidelines (Table 1). The guideline values represent the 240 concentration at which the water is safe to drink over a lifetime consumption. For example, a 241 provisional guideline value of $1.0 \mu \mathrm{g} / \mathrm{L}$ is recommended by WHO for microcystin-LR upper 242 limit concentration in water [52]. Guideline calculation is based on the daily water intake, body 243 weight and the concentration of toxins [52].

244 Table 1: Common cyanotoxins produced by cyanobacteria and their effects on human health

\begin{tabular}{|c|c|c|c|c|c|}
\hline Cyanotoxins & Health effects & $\begin{array}{l}\text { Genera of main } \\
\text { producers }\end{array}$ & $\begin{array}{l}\text { Bloom } \\
\text { concentration } \\
(\mu \mathrm{g} / \mathrm{L})\end{array}$ & $\begin{array}{l}\text { Drinking } \\
\text { water } \\
\text { Guideline } \\
(\mu \mathrm{g} / \mathrm{L})\end{array}$ & References \\
\hline \multicolumn{6}{|l|}{ Hepatoxins } \\
\hline Microcystis & $\begin{array}{l}\text { Acute exposure: } \\
\text { abdominal pain, } \\
\text { headache, nausea, } \\
\text { skin irritation } \\
\text { Ingestion of } \\
\text { significant levels: } \\
\text { liver damage and } \\
\text { dysfunction }\end{array}$ & $\begin{array}{l}\text { Anabaena } \\
\text { Planktothrix } \\
\text { Microcystis }\end{array}$ & $15-100000$ & $\begin{array}{l}1.0 \text { (WHO) } \\
1.3 \\
\text { (Australia) }\end{array}$ & {$[53,52,54]$} \\
\hline Nodularins & $\begin{array}{l}\text { Skin and eye } \\
\text { irritation, allergic } \\
\text { reaction } \\
\text { Disruption to liver } \\
\text { structure }\end{array}$ & Nodularia & $\begin{array}{c}0-2.2 \\
\text { Highest record: } \\
42300\end{array}$ & $\begin{array}{c}1.0 \\
\text { Microcystis } \\
- \text { LR } \\
\text { (WHO) }\end{array}$ & {$[52,55,56]$} \\
\hline
\end{tabular}


Acute exposure:

fever, headache, Cylindrospermo

vomiting, bloody $\quad$ psis raciborskii, Commonly $10-$

Cylindrospermo diarrhea Aphanizomenon 100

psins

Inhibition of

ovalisporum, $A p$

High record 589

1.0

$[43,57-59]$

protein synthesis, hanizomenon $\quad-800$

kidney damage, zflos-aquae

liver necrosis

\section{Neurotoxins}

\begin{tabular}{|c|c|c|c|c|c|}
\hline \multirow{6}{*}{$\begin{array}{l}\text { Anatoxin-a } \\
a(s) \text { group }\end{array}$} & \multicolumn{5}{|l|}{ Neurotransmitter } \\
\hline & & Anabaena & & 3.7 & \\
\hline & overexcite muscle & Anhanizomenon & $154-1000$ & (Quebec) & {$[44 \quad 60-62]$} \\
\hline & cells causing & Planltothrix. & & $6(\mathrm{New}$ & \\
\hline & exhaustion, & & & Zealand) & \\
\hline & paralysis & & & & \\
\hline
\end{tabular}

\section{Dermatotoxin}

\begin{tabular}{|c|c|c|c|c|c|}
\hline Lyngbyatoxin-a & Skin irriation & Planktothrix & 279 & $\mathrm{~N} / \mathrm{A}$ & {$\left[\begin{array}{lll}49 & 63 & 64\end{array}\right]$} \\
\hline Aplysiatoxin & Rashes, blisters & Lyngbia & & & \\
\hline
\end{tabular}

\subsection{Water quality}

247 Cyanobacterial blooms affect and alter the characteristics and quality of the waterbody.

248 These include the changes in the water colour, $\mathrm{pH}$, dissolved oxygen (DO) level and the

249 presence of unpleasant odours. In the long-term, cyanobacterial blooms can have significant

250 impacts on the ecosystems within the waterbody. The aesthetic value of recreational water

251 bodies is reduced when cyanobacterial blooms occur. Accumulation of cyanobacterial scums

252 on the water surface and along the shoreline is aesthetically displeasing. It can cause clear water

253 to appear green and murky. Blooms can also result in earthy or musty odours and poor taste.

254 This is caused by the production of taste and odour compounds (i.e. Geosmin and 2-methyl-

255 isoborneol from cyanobacterial biomass. Anabaena, Planktothrix, Oscillatoria,

256 Aphanizomenon, Lyngbia, and Symploca are common species that contain known geosmin and

257 2-methyl-isoborneol $[65,66]$. Human taste-and-odour detection threshold for these compounds

258 are as low as $10 \mathrm{ng} / \mathrm{L}$ [67], making the presence of these in water for recreational use an

259 unpleasant issue. 
The water $\mathrm{pH}$ and DO level also significantly affected by cyanobacterial blooms. During photosynthesis, cyanobacteria uptake carbon dioxide and consequently raise the $\mathrm{pH}$ by increasing the level of hydroxide. On the other hand, during the cyanobacteria cell lysis, $\mathrm{pH}$ level is reduced [68]. An increase or reduction in $\mathrm{pH}$ can be unfavourable for the ecosystems since many aquatic species prefer a stable $\mathrm{pH}$ range $[69,70]$. Cyanobacteria uptake oxygen for their aerobic respiratory activities during the night time [71], causing the DO level to decrease. Degradation of dead cyanobacterial cells after blooms also requires oxygen [68]. The increase in biochemical oxygen demand (BOD) and oxygen depletion caused by cyanobacteria make it more competitive for other aquatic species to thrive.

\subsection{Socio-economic impacts}

Cyanobacterial blooms can disrupt the socio-economic stability due to their potential toxicity and impacts on water quality. Significant impacts are reported on industries such as tourism, agriculture, real estate and public health sector [72, 73]. Unfortunately, recent costanalysis of these impacts are limited while available documents are dated back to the 1990s and 2000s. An example of a comprehensive report on financial damage caused by several cyanobacterial blooms were reviewed by Steffensen [7] for Australia in 2008 (Table 2). The impact on tourism was mainly due to the prohibition of recreational activities (e.g. fishing, camping, swimming) near bloom affected areas [7]. A study on cyanobacterial blooms from 1990 to 1999 in England and Wales [74] reported the damage costs to be \$105-160 million per year. Dodds et al. estimated an annual economic loss of more than one billion dollars in the United States due to harmful cyanobacterial blooms in 2008 [75]. Due to the rapid change in economic condition, the monetary values of socio-economic impacts in the event of 


\begin{tabular}{|c|c|c|c|c|}
\hline Year & Location & $\begin{array}{l}\text { Type of } \\
\text { blooms }\end{array}$ & $\begin{array}{l}\text { Cost to } \\
\text { social/tourism } \\
\text { revenue }\end{array}$ & $\begin{array}{l}\text { Impact on } \\
\text { agriculture/industries }\end{array}$ \\
\hline 1997 & Darling River & Anabaena & $\$ 1.5$ million & 1600 livestock death \\
\hline 1991/1992 & $\begin{array}{l}\text { Hawkesbury Nepean } \\
\text { River }\end{array}$ & Non-toxin & $\$ 6.7$ million & $\mathrm{N} / \mathrm{A}$ \\
\hline 1987-1992 & $\begin{array}{l}\text { Water reserviors in New } \\
\text { South Wales }\end{array}$ & $\begin{array}{l}\text { Anabaena } \\
\text { Nodularia }\end{array}$ & $\$ 1.2$ million & $\mathrm{N} / \mathrm{A}$ \\
\hline
\end{tabular}

Monitoring measures to identify the presence and prevent the progression of cyanobacterial blooms also induce immediate costs. For example, Hamilton City Council in New Zealand spent $\$ 1,000$ a day in early 2003 to treat the city's drinking water with powdered activated carbon in response to a potential saxitoxins bloom [76]. For cyanotoxin detection, toxicity

294 tests may cost over $\$ 1000$ per sample [7], although this cost will depend on the size of the 295 blooms and facilities available for assessing.

The cost for the actions taken subsequently to control and remove the blooms (e.g. artificial mixing and algicides) is site-specific and could involve extra expenses. For example, \$1 million

298 is spent each year by South Australia Water to treat cyanobacterial blooms using copper-based

299 algicide. This includes the dispose of the copper contaminated water treatment sludge as many 300 aquatic organisms could be negatively impacted by copper [7]. Pretty et al. [74] also reported 301 an expense of $\$ 77$ million per year to address the damages from cyanobacterial blooms in 302 England and Wales.

\section{Cyanobacterial bloom control and treatment}

Effective cyanobacterial bloom control requires a holistic approach with well-integrated management and technology measures as well as a focus on the prevention strategies to minimise impact costs. Technologies are incorporated to effectively detect and control the development of cyanobacterial blooms and cyanotoxins (Fig. 2). 


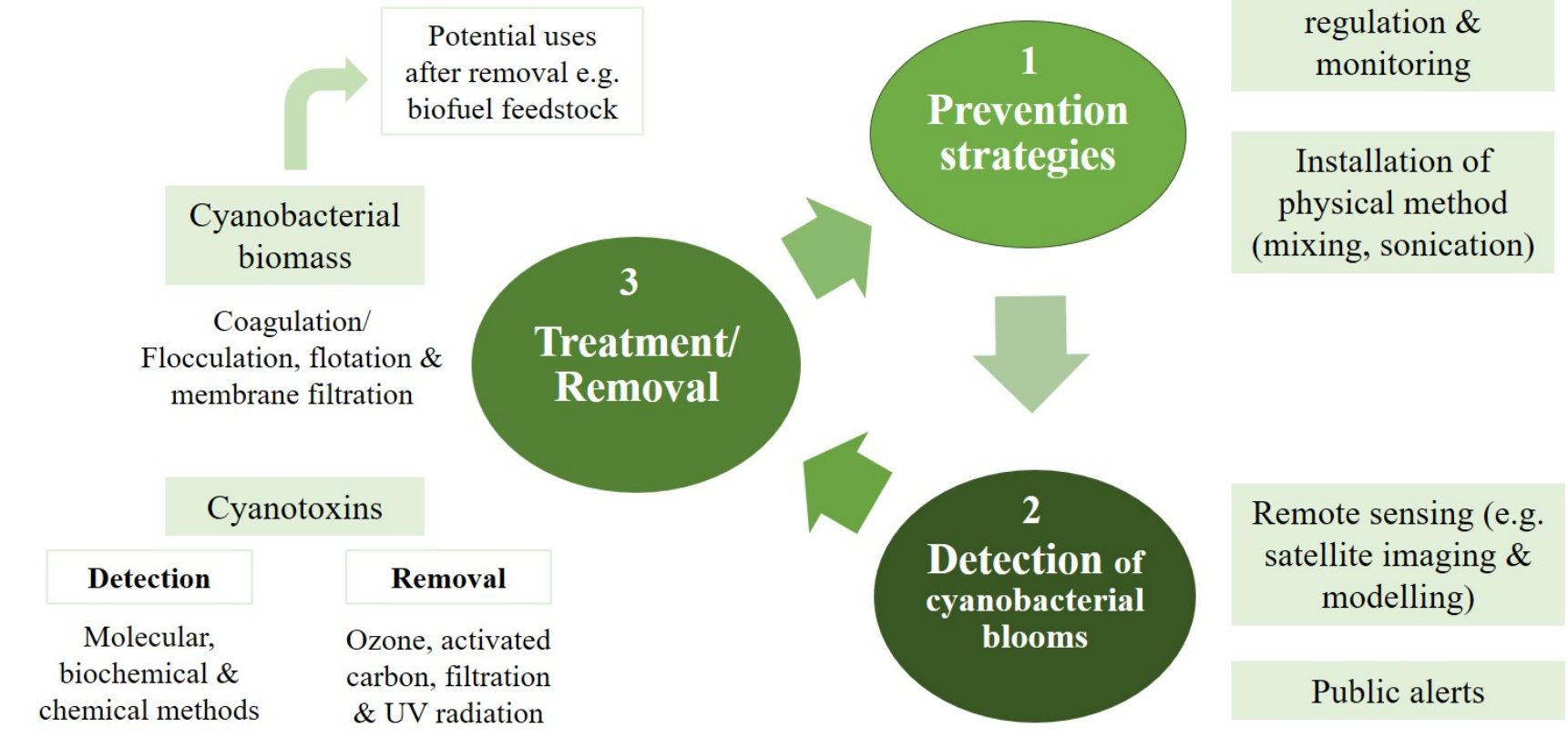

Figure 2: Cyanobacterial management response cycle.

\section{$311 \quad 4.1 \quad$ Prevention strategies}

312 The focus of preventive measures for cyanobacterial blooms includes (i) restricting the 313 nutrient availability for cyanobacterial growth, (ii) facilitating changes in hydrodynamics that 314 are unflavoured for blooms and (iii) making improvements towards climate change. Nutrient 315 management tackles the root of the problem by limiting nutrient availability in the water bodies $316[2,77]$. Phosphorus has been identified as a key bloom promoting factor [78-80]. Recent studies

317 have also highlighted the importance of nitrogen in supporting biomass and toxigenicity [81-

318 83]. Measures to reduce external phosphorus inputs such as bans on phosphates in detergents,

319 minimising the use of synthetic fertilisers and improved sewage treatment have been effective $320[2,81]$. In-lake methods such as hypolimnetic aeration and oxygenation to reduce internal 321 phosphorus loading from sediments have succeeded in some cases [84-86]. In the 1990s, 322 Australian CSIRO had developed lanthanum modified bentonite (commercially known as 323 Phoslock $^{\circledR}$ ), an innovative phosphorous binding clay [87, 88]. Phoslock has proved to 324 effectively remove total and soluble reactive phosphorus [89]. Meanwhile, due to its complex 325 gaseous atmospheric cycle, nitrogen loading is more difficult to manage and can be costly [81, 326 90]. Construction of wetlands and vegetative riparian buffers are effective ways to reduce non- 
diffuse sources of both phosphorus and nitrogen (e.g. agricultural and stormwater runoff) [91, 92]. These systems can also limit light availability to the surface cyanobacteria by shading the water, thus mitigate bloom development near shore.

330 Mixing can effectively mitigate cyanobacterial growth. Stagnant water allows buoyant cyanobacteria to remain stable in the upper layer abundant of light and warmth, thus promoting 332 bloom development. By applying mixing, the stability of the water column is decreased while 333 the mixing water depth is increased. As a result, cyanobacteria entrained in turbulence experience lower light availability, higher light fluctuation and shorter residence time. This leads to a decrease in cyanobacterial growth [18]. Some examples include introducing plumes of bubbles near the bottom of the reservoir or installing a propeller in/near the dam wall.

Sonication has emerged as a promising technique to control cyanobacterial bloom [93, 94]. Ultrasonic radiation in water can generate cavitation bubbles, causing localised regions of very high temperature and pressure [95]. This extreme environment disrupts the structure of the gas vacuoles in algal cells thus inhibiting the buoyancy of cyanobacteria. Without the competitive ability for buoyancy, the photosynthetic activity of cyanobacteria is limited. Simultaneously, the sedimentation of collapsed algal cells is stimulated [96]. This leads to a decline in cyanobacterial growth. Sonication is simple and easy to operate, with low impact on the ecosystems [93].

Improvements towards climate change and global warming also contribute to minimising cyanobacterial blooms in the long term. Currently, climate change affects cyanobacterial development in many ways $[2,81]$. Higher water temperature due to global warming stimulates vertically thermal stratification, which favours the growth of cyanobacteria. Increased water variability (e.g. severe storms and rainfall) due to climate change may results in more nutrient runoff into the water bodies. Therefore, efforts in decelerating climate change can generate positive impacts on the long-term cyanobacterial bloom management. Successful prevention and management of cyanobacteria in surface water require the engagement of the wider community (e.g. water managers, users, scientists, engineers) [77]. Collaborations among these parties to develop a tailor-made and integrated solution for the water body of interest is encouraged. 


\subsection{Detection of cyanobacterial bloom development}

357

358

359

360

361

362

363

364

365

366

367

368

369

370

371

372

373

374

375

376

377

378

379

380

381

382

383

384

385

386

Remote sensing technologies (using satellite, drone, and hyperspectral cameras) accompanied by advanced modelling (e.g. artificial neural networks) offers cost-effective and efficient ways to forecast and monitor cyanobacterial blooms [97, 98]. These have been implemented by CSIRO and Australian water authorities (WaterNSW and Melbourne Water) to develop a harmful algal bloom early warning system [8]. Based on historical data and the information collected from the hyperspectral camera, changes in the physical environment (temperature and wind) that could lead to cyanobacterial blooms are detected. This together with satellite remote sensing imagery allows for risk assessment of cyanobacterial blooms and their potential spatial spread [8]. Prediction of cyanobacterial development seven to 14 days ahead can be achieved through these approaches. This allows adequate time for early intervention (e.g. chemical dosing, apply mixing) to minimise a further growth of cyanobacteria [8].

Historical and current satellite data is also used to detect cyanobacterial blooms in U.S. freshwater systems in a project called Cyanobacteria Assessment Network (CyAN). This project was facilitated in 2015 by multiple agencies, including the EPA, NASA, the National Oceanic and Atmospheric Administration (NOAA), and the United States Geological Survey (USGS) [99]. CyAN seeks to develop an integrated and reliable system to predict and identify cyanobacterial blooms across the U.S. using satellites. The harmful level of these in various water storages can also be characterised using the data from colour satellites [99].

Public alerts for cyanobacteria detection provide up-to-date information for all water suppliers and users and prevent undesirable accidents related to cyanobacterial blooms. These could include media statements, signage and direct advice from the authorities. An online cyanobacteria alert system is particularly effective in delivering real-time update on the bloom development. The data collected from remote sensing is a good input for this type of systems.

An example of the online algal alert maps is provided by the Regional Algal Coordinating Committees (RACCs) across New South Wales, Australia [100]. Three colour-coded alert levels are used to represent the level of cyanobacteria in the water. They are declared once the algal cell numbers exceed the concentration in the Guidelines for Managing Risk in Recreational Waters [4] (Table 3). 
387 Table 3: Algal alert modes managed by the RACCs across New South Wales, Australia [100]

\begin{tabular}{cccc}
\hline Alert mode & \multicolumn{2}{c}{ Detected concentration } & Hazardous level \\
\cline { 2 - 3 } & cells/mL of Microcystis & $\begin{array}{c}\mathrm{mm}^{3} / \mathrm{L} \text { of combined total } \\
\text { cyanobacteria }\end{array}$ & \\
\hline Green & $500-5000$ & $0.04-0.4$ & Low $^{\mathrm{a}}$ \\
\hline Amber & $5000-50000$ & $0.4-4$ & High $^{\mathrm{b}}$ \\
\hline Red & 50000 & 4 & Extreme $^{\mathrm{c}}$
\end{tabular}

$388{ }^{a}$ Cyanobacterial bloom at earlier stages do not pose any threats to recreational, stock or domestic use [4]

$389{ }^{\mathrm{b}}$ The water is no longer safe for potable use. Recreational uses are still suitable but should be taken with cautions

390 as the cyanobacteria population can now change rapidly [100].

$391{ }^{c}$ The waterbody is prohibited for any primary recreational use. The public should be notified through media

392 channels and signage around the location of blooms.

$393 \quad 4.3$ Cyanobacterial biomass removal

394 A range of techniques has been used for removing and harvesting cyanobacterial biomass

395 (and intracellular cyanotoxins) from a water suspension [101]. The most common techniques

396 include coagulation and flocculation, flotation, membrane filtration and centrifugation (Table

397 4). The deployment of these techniques often focuses on several factors i.e. ease of use, removal

398 efficiency, operational cost, energy demand, operation scale and quality of harvested algal

399 biomass. It is also common to combine two or more techniques to achieve desirable operation

400 and efficiency [102].

401

402

403

404

405

406

407

408

409 
410 Table 4: Advantages and disadvantages of common removal techniques for cyanobacteria

411 biomass

\begin{tabular}{llll}
\hline Removal & Advantages & Disadvantages & References \\
Techniques & &
\end{tabular}

\begin{tabular}{|c|c|c|c|}
\hline $\begin{array}{l}\text { Coagulation/ } \\
\text { Flocculation }\end{array}$ & $\begin{array}{l}\text { Fast and easy } \\
\text { Less cell damages } \\
\text { Suitable for wide range of } \\
\text { species } \\
\text { Less energy demand, Suitable } \\
\text { for large scale }\end{array}$ & $\begin{array}{l}\text { High chemical cost } \\
\text { Highly } \mathrm{pH} \text { dependent } \\
\text { Efficiency varies across types of } \\
\text { flocculants } \\
\text { End-product value is limited }\end{array}$ & {$[103]$} \\
\hline $\begin{array}{l}\text { Flotation (e.g. } \\
\text { DAF) }\end{array}$ & $\begin{array}{l}\text { Suitable for large scale } \\
\text { Low cost } \\
\text { Short operation time } \\
\text { Effective due to cyanobacteria } \\
\text { cells' buoyancy }\end{array}$ & $\begin{array}{l}\text { Addition of flocculants or } \\
\text { surfactants is required } \\
\text { pH dependent }\end{array}$ & $\begin{array}{l}{[103,} \\
40]\end{array}$ \\
\hline $\begin{array}{l}\text { Membrane } \\
\text { Filtration }\end{array}$ & $\begin{array}{l}\text { High recovery efficiency } \\
\text { No chemical required } \\
\text { Water can be recycled }\end{array}$ & $\begin{array}{l}\text { Membrane fouling leads to } \\
\text { increased O\&M cost } \\
\text { Slow operation } \\
\text { High energy demand }\end{array}$ & {$[103,40]$} \\
\hline Centrifugation & $\begin{array}{l}\text { High recovery efficiency } \\
\text { Suitable for large scale } \\
\text { Fast and continuous process }\end{array}$ & $\begin{array}{l}\text { High capital cost } \\
\text { High energy demand }\end{array}$ & {$[105,106]$} \\
\hline
\end{tabular}

\section{$413 \quad 4.4$ Cyanotoxin detection and removal}

414 Identification of the toxicological potential of cyanobacterial blooms can be obtained

415 through molecular techniques. These include polymerase chain reaction (PCR) - based methods

416 and Desoxyribonucleic Acid (DNA) microarrays [107, 41]. Conventional and real-time

417 polymerase chain reaction (qPCR) method are readily available and cost-effective ways to

418 detect cyanotoxins, even at trace level [108]. Accurate detection is achieved through the

419 amplification of the targeted toxin genes using primers if they are presented in the sample. The

420 qPCR technique particularly allows for the indirect determination of the number of target genes

421 [41, 108]. DNA microarrays are a recent technique used to detect and quantify cyanotoxins 
using their genomic DNA. Microcystins and nodularins have been identified using this technique $[109,110]$. Although DNA microarray requires a high cost, it can provide rapid toxin detection [41].

Biochemical properties of cyanotoxins allow for the development of detection methods such as enzyme-linked immunosorbent assays (ELISA) and protein phosphatase inhibition assay (PPIA). Commercially available ELISA is an easy and inexpensive method for cyanotoxin testing [111]. ELISA relies on highly specific antibody-antigen interaction to detect cyanobacterial cells [112]. Currently, cyanotoxins that can be assessed and quantified by ELISA are microcystin, nodularin, cylindrospermopsin, saxitoxin and BMAA [112-114]. PPIA was developed based on the ability of cyanotoxins to inhibit the activity of protein phosphatase enzymes [41]. In the PPIA test, inhibition of protein phosphatase indicates toxin concentration. However, PPIA cannot distinguish among microcystin variants or between microcystin and nodularin despite them having a different reaction with phosphatase. The results, therefore, are expressed as equivalent MC-LR/L [41].

A range of chemical methods such as liquid-based separations and mass spectrometry are available for identification and quantification of cyanotoxins in water. Common cyanotoxins (e.g. Microcystins) can be identified using reversed-phase high-performance liquid chromatography (RP-HPLC). This allows for the separation of cyanotoxin molecules on the basis of hydrophobicity [115]. On the other hand, hydrophilic interaction liquid chromatography (HILIC) is useful for detecting very polar cyanotoxins (e.g. Saxitoxins and $\beta$ N-methylamino-L-alanine (BMAA)) [41]. The mechanism involves the interaction between polar cyanotoxins and the stationary aqueous phase at the packing surface [116]. Recently, a combined RP-HPLC and HILIC system has emerged as a potential approach to simultaneously separate lipophilic and hydrophilic cyanotoxins [117]. Combination of liquid chromatography (e.g. HPLC or HILIC) and mass spectrometry (MS) is also a powerful analytical technique that delivers sensitive and selective results for toxin determination [112, 117]. These analytical methods provide accurate detection and quantification of cyanotoxins in environmental samples. However, a high level of expertise and expensive equipment are required to operate these systems [112].

Extracellular cyanotoxins can be removed from water using several techniques including ozonation, UV radiation and activated carbon (Table 5). These techniques are effective for degrading common cyanotoxins microcystis, cylindrospermosin and anatoxin-a [40]. 
454 Cyanotoxin saxitoxins appear to be well removed using granular activated carbon [118].

455 Cyanobacterial blooms can contain several types of cyanotoxins; thus, it is recommended to 456 combine these techniques for a better removal efficiency.

457 Green Liver Concept or Systems is a method to remove extracellular cyanotoxins based on 458 plants' capabilities to uptake, metabolise and store cyanotoxins in their cell wall fractions [119, 459 120]. This occurs during plants' biotransformation process similar to that of animal's liver. The 460 suitable aquatic plants thus act as "green liver" to remediate contaminated water and pack away 461 cyanotoxins at a low cost. Periodical harvesting of the aquatic macrophytes in this system is 462 necessary to prevent the release of cyanotoxins from degrading plants back into the water [120]. 463 Green Liver concept is a promising approach to sustainably remove extracellular cyanotoxins.

464 Multiple techniques (e.g. oxidation, coagulation, sedimentation and filtration) are often 465 incorporated into a drinking water treatment design (Fig. 3) [102]. Different removal mechanisms offered by these techniques can assist one another thus enhancing the total cyanobacteria and cyanotoxin removal efficiency. Pre-treatment techniques require careful consideration to avoid cell lysis and subsequent cyanotoxin release. For example, many drinking water treatments in Vietnam apply pre-chlorination as an algaecide. However, cyanobacterial cell's membrane can be severely disrupted by chlorine, leading to cell lysis and extracellular cyanotoxins being liberated into drinking water [121]. The combination of treatment techniques can be determined by the quality of the water source. This data can be obtained through regular monitoring and testing across the plant. Long-term strategies to prevent cyanobacterial bloom in the source water should, therefore, be prioritised. 
483 Table 5: Advantages and disadvantages of common removal techniques for cyanotoxins

\begin{tabular}{|c|c|c|c|}
\hline $\begin{array}{l}\text { Removal } \\
\text { Techniques }\end{array}$ & Advantages & Disadvantages & References \\
\hline Ozonation & $\begin{array}{l}\text { Effective for Microcystis, } \\
\text { Cylindrospermosin, Anatoxin-a } \\
\text { and T\&O } \\
\text { Quick reaction time } \\
\text { Ease to automate }\end{array}$ & $\begin{array}{l}\mathrm{pH} \text { dependent for oxidation of } \\
\text { some species } \\
\text { Possible formation of } \\
\text { disinfection by-products }\end{array}$ & {$[40]$} \\
\hline Activated carbon & $\begin{array}{l}\text { Effective and affordable } \\
\text { Suitable for large scale }\end{array}$ & $\begin{array}{l}\text { Effectiveness varies among } \\
\text { types of carbon and pore size }\end{array}$ & {$[40]$} \\
\hline UV radiation & $\begin{array}{l}\text { Degrade Microcystis, } \\
\text { Cylindrospermosin, Anatoxin-a } \\
\text { Require less space } \\
\text { No impact on water composition }\end{array}$ & $\begin{array}{l}\text { Specific UV emission spectrum } \\
\text { for each toxin } \\
\text { Require high doses or addition } \\
\text { of photocatalyst/hydrogen } \\
\text { peroxide }\end{array}$ & {$[101,35]$} \\
\hline $\begin{array}{l}\text { Green Liver } \\
\text { concept }\end{array}$ & $\begin{array}{l}\text { Low cost, sustainable green } \\
\text { technology } \\
\text { Toxins completely taken up by } \\
\text { the aquatic plants }\end{array}$ & $\begin{array}{l}\text { Require periodical harvesting } \\
\text { and planting of new plant } \\
\text { Possible release of cyanotoxins } \\
\text { back into the water }\end{array}$ & {$[120]$} \\
\hline
\end{tabular}




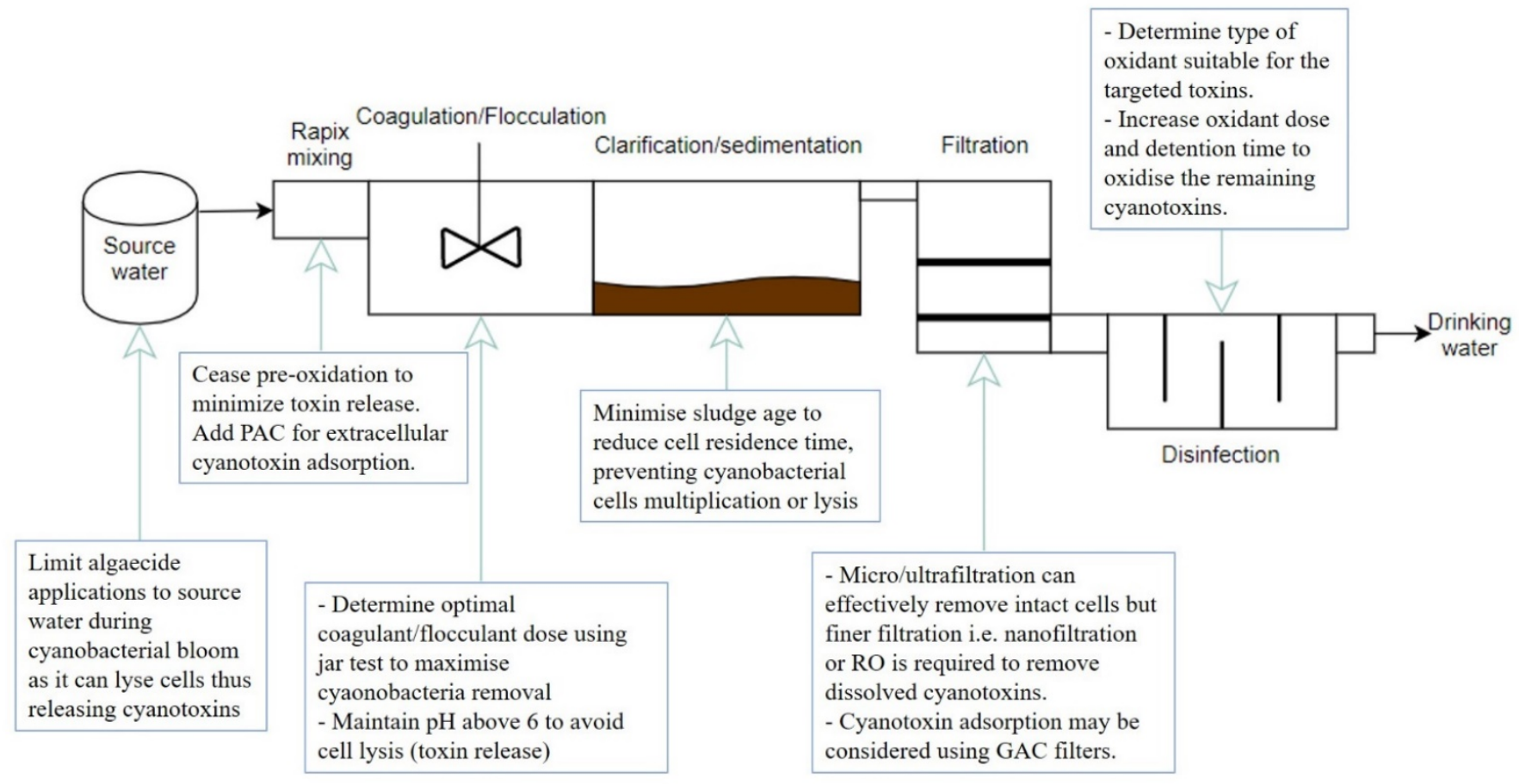

486 Figure 3: The schematic of drinking water treatment processes with considerations for 487 effective cyanobacterial biomass and cyanotoxins removal based on recommendations and 488 evaluations developed by EPA [102].

\section{Opportunities from cyanobacteria}

490 The metabolic diversity allows cyanobacteria to possess a range of bioactive compounds.

491 Not all of these bioactive compounds are toxic. Indeed, many of them are valuable for the food, 492 health, cosmetic and pigment industry (Fig. 4). In addition, the photosynthetic capacity of 493 cyanobacteria makes them one of the most promising feedstocks for solar-powered biofuel 494 production (Fig. 4). 


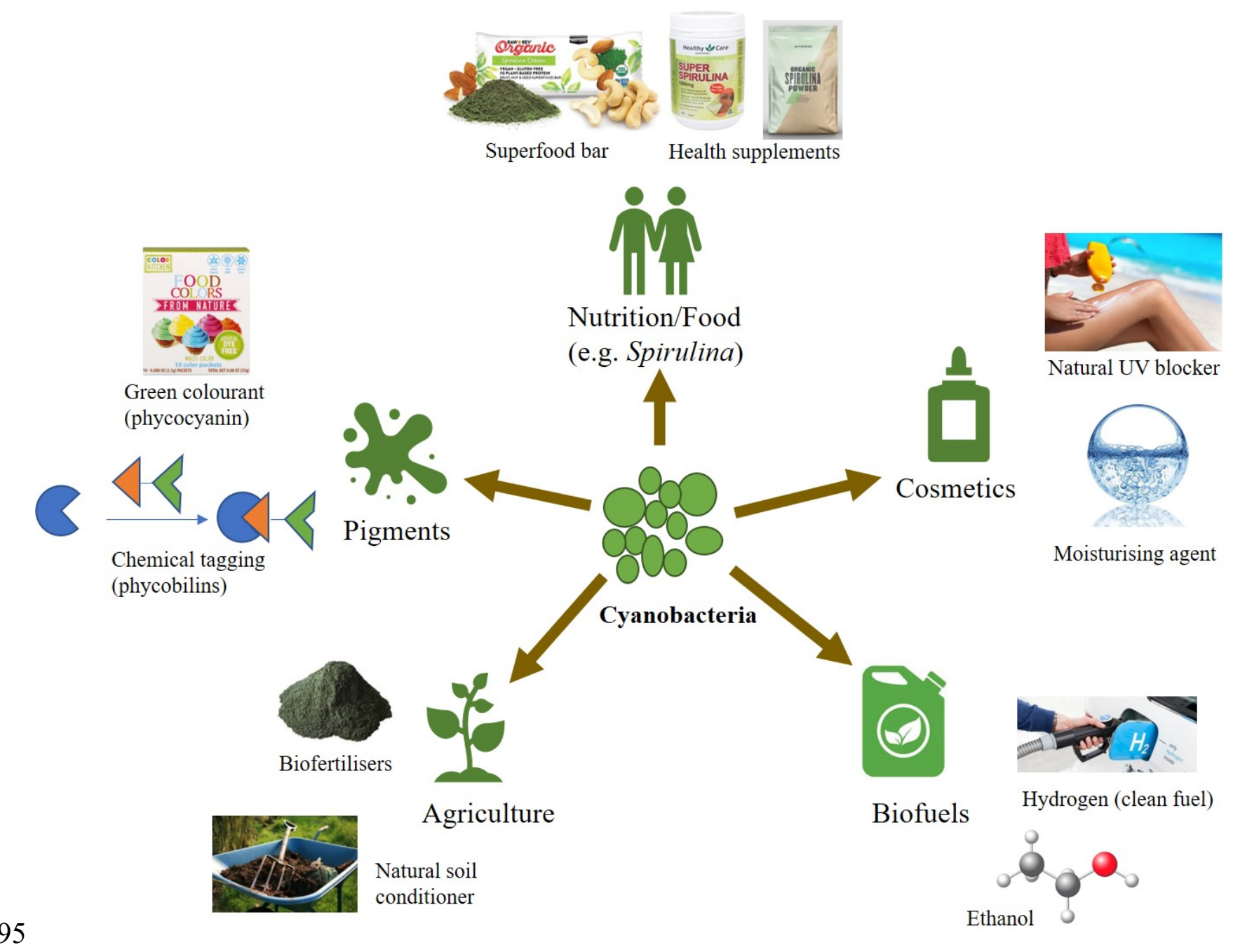

Figure 4: Potential applications of cyanobacterial biomass.

497

498

\subsection{Human food}

499 Cyanobacteria biomass has been a traditional food source for centuries. Kanembu people 500 in central Africa and the indigenous population in Asia and North America are known to 501 consume Spirulina as a nutritious food [19]. It is a high protein content (65\%) superfood in comparison to most other natural food such as animal and fish flesh (15-25\%), soybean (35\%) and eggs (12\%). Vitamins extracted from cyanobacterial biomass have also been used for

504 health care. A rich amount of carotene, thiamine, riboflavin and vitamin B can be harvested 505 from Spirulina [122].

506 Several secondary metabolites from cyanobacteria (polysaccharides, essential fat gamma507 Linolenic acid) can be easily absorbed by human cell thus improving energy production. In 508 addition, researchers have identified potential health-promoting effects from Spirulina 
509 consumption (e.g. suppression of hypertension and elevated serum glucose level, alleviation of 510 hyperlipidaemia) $[123,124]$.

511 Commercial production of these cyanobacteria into "nutraceuticals" (food supplements 512 marketed with nutritional and medicinal benefits) have been facilitated over that last few

513 decades. Spirulina is a dominating species in commercial cyanobacterial biomass production 514 with an estimated global output of 2,000 tonnes a year $[125,126]$. The largest cultivation farm 515 is in Hainan China (Hainan Simai Enterprising Ltd) and produces 200 tonnes of Spirulina 516 powder annually. Further research to optimise the harvesting and extraction of valuable 517 compounds from cyanobacteria will establish an economic and environmental-friendly food 518 industry for the future.

\section{$519 \quad 5.2 \quad$ Essential ingredients for cosmetic products}

520 Bioactive compounds isolated from cyanobacteria are promising resources for natural cosmetic and skincare industry. For examples, mycosporine-like amino acids are potential compounds for the production of effective natural UV blockers due to their adsorption maxima in UV range [127, 128]. These are photoprotective compounds primarily engaged in the protection of cyanobacteria against detrimental solar radiation [129, 130]. Derivatives from mycosporine-like amino acids (e.g. tetrahydropyridines) as sunscreen pigments not only prevent damage from the UV radiation but also suppress inflammation and have antioxidant activity [131-133]. However, further research is needed to validate the industrial development of natural sunscreens and other cosmetic products from mycosporine-like amino acids.

Exopolysaccharides excreted from cyanobacteria (e.g. Synechocystis) have antioxidant properties and potential use as moisturising agents [134]. Exopolysaccharides are composed of various sugars and uronic acid with water adsorption and retention capacity [12]. In a comparison between a exopolysaccharides (sacran) extracted from Aphanothece sacrum and hyaluronic acid (the most widely used ingredient in moisturising products), Okajima et al. observed that sacran had a higher water absorption efficiency $[135,136]$. Sacran, therefore, has the potential to replace expensive hyaluronic acid in the production of high moisturising products. Hence, the development of cosmetic formulations based on natural compounds from cyanobacteria is an ecologically-friendly approach to provide skin benefits without inducing side effects and high cost like synthetic products [12]. 


\subsection{Pigments as natural colorants}

540 Major groups of light-harvesting pigments (chlorophyll, phycobiliproteins and carotenoids) 541 produced by cyanobacteria are commercially valuable. Phycocyanin is a type of 542 phycobiliproteins that have been used as natural colourants in food (e.g. chewing gum, ice 543 cream, candies) [19]. It contains natural blue pigment and is abundant in cyanobacteria (e.g. 544 Spirulina, Synechococus, Anabaena) [11]. Phycocyanin as natural colourants are environment545 friendly and eliminate potential health issues using synthetic colours (toxic, carcinogenic). 546 Phycobilins (phycobiliproteins) are also used as chemical tags in research and in 547 immunofluorescence technique. This is due to their ability to bind to specific antibodies and 548 fluoresce at a particular wavelength [137].

\section{$549 \quad 5.4 \quad$ Sustainable agriculture}

550 Cyanobacteria have promising applications in the field of sustainable agriculture due to their ability to fix atmospheric nitrogen $\left(\mathrm{N}_{2}\right)$ in soil, enhance the solubility of nutrients, and act as a soil conditioner $[19,138,139]$. A natural population of cyanobacteria is present in most paddy fields [138]. Rice fields with waterlogged conditions are especially favourable for their habitation $[19,138]$. Cyanobacteria as biofertiliser in rice field can contribute to about $20-30$ $\mathrm{kg} \mathrm{N} / \mathrm{ha}$ [140]. It thereby reduces the investment into chemical fertilisers without compromising with the normal yield. Nutrient availability (i.e. phosphorus) is also improved as cyanobacteria can solubilise and mobilise the insoluble organic phosphates present in the soil $[13,141]$. The effect of cyanobacterial biofertiliser on crop growth is not spontaneous due to the gradual release of the fixed nitrogen into the soil. This enables the crops to utilise more nutrients available from the soil during growth stage [19, 138]. Examples of effective cyanobacterial biofertilisers include Anabaena variabilis, Nostoc muscorum, Aulosira fertissima, and Tolypothrix tenuis [139].

The beneficial effects of cyanobacteria inoculation in crop field have also been reported for wheat, kale and willow [142-144]. These studies indicated that besides enhancing soil fertility, cyanobacteria are effective soil conditioners. Inoculation of cyanobacteria in sandy and calcareous soils improved the soil organic matter, water holding capacity and soil aggregate stability [142]. This was presumably due to the excretion of several compounds (polysaccharides, peptides, lipids, etc.) from cyanobacterial cells which helps in binding soil particles $[19,142]$. Cyanobacteria is, therefore, an economical option to replace expensive soil conditioners for common agricultural use. 


\subsection{Feedstocks for biofuel production}

572

573

574

575

576

577

578

579

580

581

582

583

584

585

586

587

588

589

590

591

592

593

594

595

596

597

598

599

600

Several advantageous properties make cyanobacteria a good feedstock for solar-powered biofuel production [145]. Carbon rich biomass can be produced rapidly without competing for arable lands for food crops. Naturally available resources such as sunlight, water, atmospheric or water-dissolved $\mathrm{CO}_{2}$ are adequate for cyanobacterial growth. Some strains of cyanobacteria (e.g. Synechocystis sp., Synechococcus sp. and Anabaena sp.) can be easily and stably engineered for better biofuel production $[145,146]$. Excretion of fuel outside the engineered cyanobacterial cells is also favoured over intracellular fuel production in eukaryotic algae [145].

Synthetic biology and metabolic engineering approaches have been introduced to cyanobacteria since they do not possess a complete biosynthetic pathway for biofuel production [147]. Deng and Coleman [148] transformed Synechococcus species with bacterial genes from Zymomonas mobilis to create a catalysed pathway for ethanol synthesis. These genes provided two key enzymes (pyruvate decarboxylase and alcohol dehydrogenase). They degraded sugars to pyruvate, then fermented it to produce ethanol and $\mathrm{CO}_{2}$ as the only products. The engineered Synechococcus sp. PCC 6803 yielded an ethanol concentration of 0.23 g/L [148]. A similar approach was applied by Gao et.al [14] to Synechococcus, with additional disruption to the biosynthetic pathway of poly- $\beta$-hydroxybutyrate. A significantly higher ethanol yield (5.50 g/L) was achieved by the transformed Synechococcus sp. PCC 6803 [14]. Another example of engineered cyanobacteria is the transgenic S. elongatus PCC 7942 for isobutanol production. An isobutanol yield of $0.45 \mathrm{~g} / \mathrm{L}$ was achieved using this species via the artificial and nonfermentative pathway [15].

Cyanobacteria also produce molecular hydrogen $\left(\mathrm{H}_{2}\right)$, a promising clean fuel for the future $[145,149]$. The combustion of hydrogen for energy conversion does not result in any air pollution. Hydrogen has the highest energy per unit weight (141.65 MJ/kg) among all known fuels $[145,147,150]$. In cyanobacteria, nitrogenase enzymes have been reported to produce hydrogen most efficiently as a by-product of nitrogen fixation [16]. Several engineered cyanobacterial strains have been generated and evaluated for hydrogen production (Table 5). 
602 Table 5: Hydrogen production of genetically engineered cyanobacterial strains.

\begin{tabular}{lcc}
\hline Cyanobacterial strain & $\begin{array}{c}\text { Productivity } \\
(\mu \mathrm{mol} \mathrm{H} / \mathrm{mg} \text { chlorophyll*hour })\end{array}$ & References \\
\hline Synechococcus sp. PCC 7002 & 1.2 & {$[151]$} \\
Synechocystis sp. PCC 6803 & 6 & {$[152]$} \\
\hline Nostoc sp. PCC 7422 & 100 & {$[153]$} \\
\hline Nostoc linckia HA-46 & $93-105$ & {$[154]$}
\end{tabular}

603

6046 Future research roadmap

605 The knowledge of cyanotoxin production is significant for solving problems regarding 606 cyanobacterial bloom, but it is still not well understood. Cyanotoxin production is regulated by 607 cyanobacterial gene and a variety of environmental factors such as nutrients, light, temperature 608 and oxidants [155]. A few studies have been conducted to investigate the gene regulation and 609 the impact of environmental factors on various toxin production (e.g. microcystins, 610 cylindropermopsins, nodularins, and saxitoxins) [156-159]. However, since these studies were 611 conducted under different conditions and due to the complexity of each cyanobacterial system, 612 it is difficult to establish a precise understanding of toxin synthesis and regulation [155]. 613 Besides laboratory experiments, more field experiments should be conducted to determine the 614 effect of environmental triggers on toxin production. Furthermore, advances in molecular 615 research are required to obtain a clear view of toxin synthesis. Strong knowledge of toxin 616 trigger and production will allow researchers to develop preventive measures or treatments 617 against the presence of cyanotoxins in the water environment. 


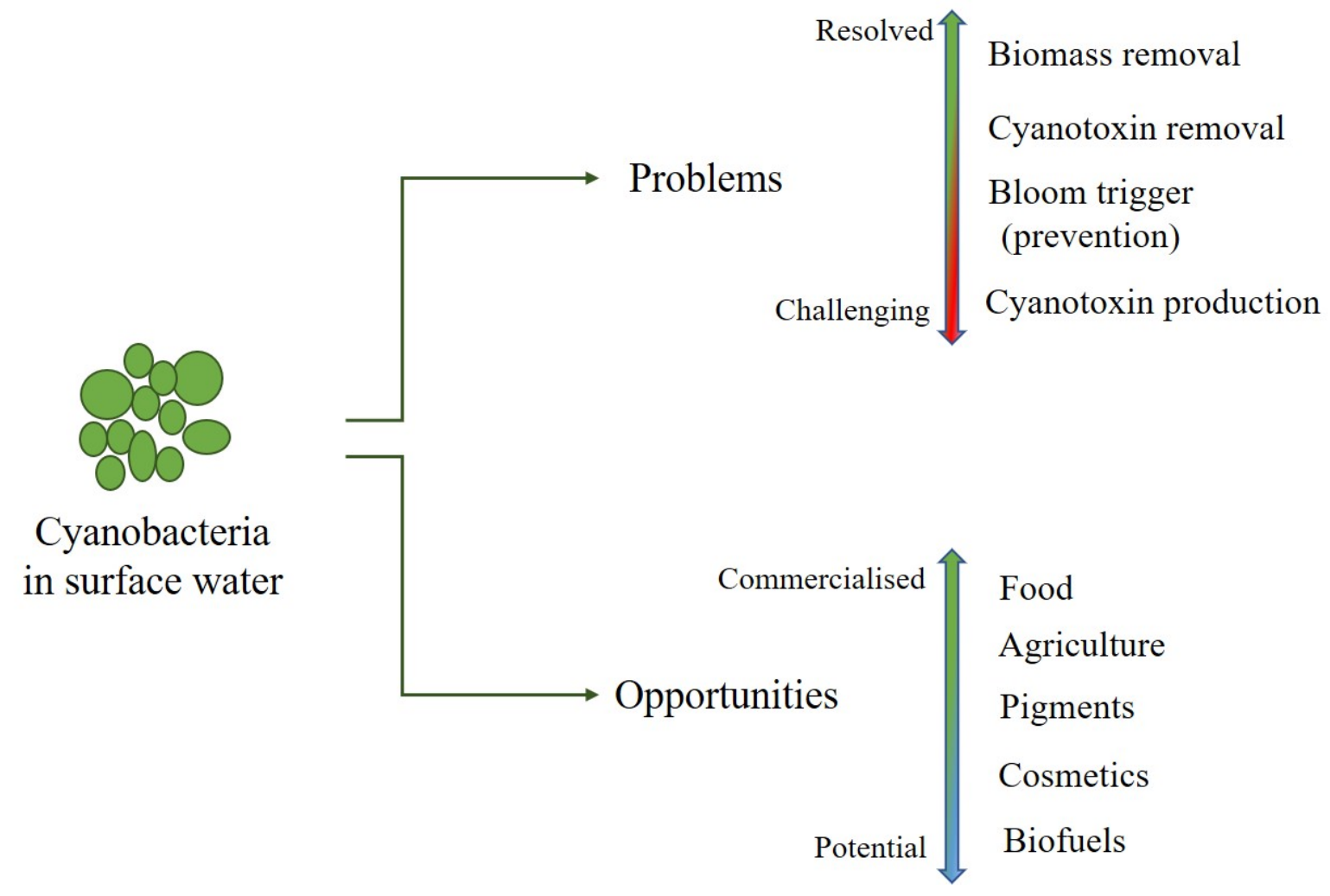

Figure 5: The current state of research on problems and opportunities associated with cyanobacteria in surface water.

623 Cyanobacteria also present many opportunities. Some applications have been 624 commercialised with demonstrated market value (e.g. Spirulina health food, biofertilisers and 625 pigments) while the others are emerging as a potential (cosmetics and biofuel) (Fig. 5). 626 Cyanobacteria biomass into biofuels can be an effective replacement to fossil fuels but there 627 are challenges in lowering the production cost. The cost of cyanobacterial cultivation and 628 processing for biofuel production is still high, making biofuel from cyanobacterial biomass 629 more expensive than fossil fuel. Besides, the use of genetically modify cyanobacteria species 630 for biofuel production require careful considerations regarding potential environmental risks. 631 Therefore, more research is still necessary to develop efficient and economically viable 632 cultivation techniques and to gain further understanding of engineered cyanobacteria.

\section{Conclusion}

634 Cyanobacteria present significant threats to human health and the environment at the time 635 of worsening climate change outlook. Harmful cyanobacterial blooms negatively cause 
impacts on the water quality, public health and the economy. Technologies have been effectively utilised to detect and remove cyanobacterial biomass and cyanotoxins from water.

638 The key to mitigating cyanobacterial bloom and its consequences relies upon prevention 639 strategies. It requires efforts in managing water quality and reducing global warming. Progress

640 in the research area of cyanotoxin production will be useful for toxic bloom prevention. Despite 641 the problems, there are also several and very significant opportunities from purposeful 642 cyanobacteria cultivation and utilisation (e.g. agriculture, food, cosmetics and pigments). 643 Recently, genetically engineered cyanobacteria attract attention as promising feedstocks for solar-powered biofuel production. Further research is still necessary to evaluate the application of these engineered cyanobacterial strains. Successful large-scale production of biofuels from cyanobacterial biomass will contribute significantly towards the global goal of sustainability.

\section{Conflict of interest}

On behalf of all authors, the corresponding author states that there is no conflict of interest.

\section{References}

650 1. Whitton BA, Potts M. Introduction to the cyanobacteria. In: Whitton BA, editor. 651 Ecology of Cyanobacteria II: Their Diversity in Space and Time. Dordrecht: Springer 652 Netherlands; 2012. p. 1-13.

653 2. Huisman J, Codd GA, Paerl HW, Ibelings BW, Verspagen JMH, Visser PM. 654 Cyanobacterial blooms. Nat Rev Microbiol. 2018;16(8):471-83. doi:https://doi.org/10.1038/s41579-018-0040-1.

3. Introduction to the cyanobacteria University of California Museum of Paleontology. https://ucmp.berkeley.edu/bacteria/cyanointro.html. Accessed 11/11 2019.

658 4. NHMRC. Guidelines for Managing Risk in Recreational Waters Canberra: National 659 Health and Medical Research Council 2008.

660 5. Qin B, Li W, Zhu G, Zhang Y, Wu T, Gao G. Cyanobacterial bloom management 661 through integrated monitoring and forecasting in large shallow eutrophic Lake Taihu (China). 662 J Hazard Mater. 2015;287:356-63. doi:https://doi.org/10.1016/j.jhazmat.2015.01.047.

663 6. Teixeira M, Costa M, Carvalho V, Pereira M, Hage E. Gastroenteritis epidemic in the 664 area of the Itaparica Dam, Bahia, Brazil. Bulletin of the Pan American Health Organization. $6651993 ; 27: 244-53$.

6667 7. Steffensen DA. Economic cost of cyanobacterial blooms. In: Hudnell HK, editor. 667 Cyanobacterial Harmful Algal Blooms: State of the Science and Research Needs. New York: 668 Springer New York; 2008. p. 855-65.

669 8. CSIRO. Blue-green algae 2019. 670 https://www.csiro.au/en/Research/Environment/Water/Blue-green-algae/Our-research.

671 9. Zervou S-K, Christophoridis C, Kaloudis T, Triantis TM, Hiskia A. New SPE-LC672 MS/MS method for simultaneous determination of multi-class cyanobacterial and algal toxins. 673 J Hazard Mater. 2017;323:56-66. doi:https://doi.org/10.1016/j.jhazmat.2016.07.020.

674 10. Sendall B, Reardon K, Hunt L, Menjivar T, Muhid P. Identification, detection \& 675 characterisation of cyanobacteria using traditional \& DNA-based methods: Forensic and 676 Scientific Services, Queensland Government. 2019. 
677 11. Udayan A, Arumugam M, Pandey A. Chapter 4 - Nutraceuticals from algae and 678 cyanobacteria. In: Rastogi RP, Madamwar D, Pandey A, editors. Algal Green Chemistry. 679 Amsterdam: Elsevier; 2017. p. 65-89.

680 12. Morone J, Alfeus A, Vasconcelos V, Martins R. Revealing the potential of 681 cyanobacteria in cosmetics and cosmeceuticals - A new bioactive approach. Algal Res. 2019;41:101541. doi:https://doi.org/10.1016/j.algal.2019.101541.

13. Pathak J, Rajneesh, Maurya PK, Singh SP, Häder D-P, Sinha RP. Cyanobacterial farming for environment friendly sustainable agriculture practices: innovations and perspectives. Front Environ Sci. 2018;6(7). doi:http://doi.org/10.3389/fenvs.2018.00007.

14. Gao Z, Zhao H, Li Z, Tan X, Lu X. Photosynthetic production of ethanol from carbon dioxide in genetically engineered cyanobacteria. Energ Environ Sci. 2012;5(12):9857-65. doi:http://doi.org/10.1039/C2EE22675H.

689 15. Atsumi S, Hanai T, Liao JC. Non-fermentative pathways for synthesis of branched690 chain higher alcohols as biofuels. Nature. 2008;451(7174):86-9. 691 doi:https://doi.org/10.1038/nature06450.

692 16. Allahverdiyeva Y, Leino H, Saari L, Fewer DP, Shunmugam S, Sivonen K et al. Screening for biohydrogen production by cyanobacteria isolated from the Baltic Sea and Finnish lakes. Int J Hydrogen Energ. 2010;35(3):1117-27. doi:https://doi.org/10.1016/j.ijhydene.2009.12.030.

696 17. Mowe MAD, Mitrovic SM, Lim RP, Furey A, Yeo DCJ. Tropical cyanobacterial 697 blooms: A review of prevalence, problem taxa, toxins and influencing environmental factors. 698 Journal of Limnology. 2015;74:205-24. doi:http://doi.org/10.4081/jlimnol.2014.1005.

699 18. Visser PM, Ibelings BW, Bormans M, Huisman JJAE. Artificial mixing to control 700 cyanobacterial blooms: a review. Aquat Ecol. 2016;50(3):423-41. 701 doi:http://doi.org/10.1007/s10452-015-9537-0.

702 19. Chakdar H, Jadhav S, Dhar D, Pabbi S. Potential applications of blue green algae. J Sci Ind Res. 2012;71:13-20. doi:http://hdl.handle.net/123456789/13322.

20. Markou G, Georgakakis D. Cultivation of filamentous cyanobacteria (blue-green algae) in agro-industrial wastes and wastewaters: A review. Appl Energ. 2011;88(10):3389-401. doi:https://doi.org/10.1016/j.apenergy.2010.12.042.

707 21. Vincent WF. Cyanobacteria. In: Likens GE, editor. Encyclopedia of Inland Waters. 708 Oxford: Academic Press; 2009. p. 226-32.

709 22. Mur LR, Skulberg OM, Utkilen H. Cyanobacteria in the environment In: Chorus I, 710 Bartram J, editors. Toxic Cyanobacteria in Water: A guide to their public health consequences, monitoring and management. World Health Organization; 1999.
23. Cyanobacteria.
Landcare

Research

https://www.landcareresearch.co.nz/resources/identification/algae/identificationguide/identify/guide/descriptions/cyanobacteria.

24. Manisha M. Cyanobacteria: occurrence, morphology and cell structure. http://www.biologydiscussion.com/bacteria/cyanobacteria/cyanobacteria-occurrencemorphology-and-cell-structure/52036.

25. Reynolds CS, Oliver RL, Walsby AE. Cyanobacterial dominance: The role of buoyancy regulation in dynamic lake environments. New Zeal J Mar Fresh. 1987;21(3):379-90. doi:http://doi.org/10.1080/00288330.1987.9516234.

26. Kumar K, Dasgupta CN, Nayak B, Lindblad P, Das D. Development of suitable photobioreactors for $\mathrm{CO} 2$ sequestration addressing global warming using green algae and $\begin{array}{lll}\text { cyanobacteria. } & \text { Bioresource } & \text { Technol. }\end{array}$

724 doi:https://doi.org/10.1016/j.biortech.2011.01.054. 

of carbon dioxide and production of biomolecules using cyanobacteria. J Environ Manage. 2018;218:234-44. doi:https://doi.org/10.1016/j.jenvman.2018.04.031.

28. Atia A, Saad A. Review on freshwater blue-green algae (cyanobacteria): occurrence, classification and toxicology. Biosci Biotechnol Res Asia. 2014;11:1319-25. doi:https://doi.org/10.13005/bbra/1522.

29. Smith VH. Low nitrogen to phosphorus ratios favor dominance by blue-green algae in $\begin{array}{lll}\text { lake } \quad \text { Shytoplankton. } & \text { Science. }\end{array}$ doi:http://doi.org/10.1126/science.221.4611.669.

30. Dao TS, Nimptsch J, Wiegand C. Dynamics of cyanobacteria and cyanobacterial toxins and their correlation with environmental parameters in Tri An Reservoir, Vietnam. Journal of Water and Health. 2016;14(4):699-712. doi:http://doi.org/10.2166/wh.2016.257

737 31. O'Neil JM, Davis TW, Burford MA, Gobler CJ. The rise of harmful cyanobacteria blooms: The potential roles of eutrophication and climate change. Harmful Algae. 2012;14:313-34. doi:https://doi.org/10.1016/j.hal.2011.10.027.

740 32. Paerl HW, Huisman J. Climate change: A catalyst for global expansion of harmful cyanobacterial blooms. Environ Microbiol Rep. 2009;1(1):27-37. doi:http://doi.org/10.1111/j.1758-2229.2008.00004.x.

33. Watson SB, McCauley E, Downing JA. Patterns in phytoplankton taxonomic composition across temperate lakes of differing nutrient status. Limnol Oceanogr. 1997;42(3):487-95. doi:http://doi.org/10.4319/lo.1997.42.3.0487.

746 34. Trimbee AM, Prepas EE. Evaluation of total phosphorus as a predictor of the relative biomass of blue-green algae with emphasis on Alberta lakes. Can J Fish Aquat Sci. 1987;44(7):1337-42. doi:http://doi.org/10.1139/f87-158.

35. Merel S, Walker D, Chicana R, Snyder S, Baurès E, Thomas O. State of knowledge and concerns on cyanobacterial blooms and cyanotoxins. Environ Int. 2013;59:303-27. doi:https://doi.org/10.1016/j.envint.2013.06.013.

36. Montechiaro F, Giordano M. Effect of prolonged dark incubation on pigments and photosynthesis of the cave-dwelling cyanobacterium Phormidium autumnale (Oscillatoriales, Cyanobacteria). Phycologia. 2006;45(6):704-10. doi:http://doi.org/10.2216/06-15.1.

37. Visser PM, Verspagen JMH, Sandrini G, Stal LJ, Matthijs HCP, Davis TW et al. How rising $\mathrm{CO} 2$ and global warming may stimulate harmful cyanobacterial blooms. Harmful Algae. 2016;54:145-59. doi:https://doi.org/10.1016/j.hal.2015.12.006.

38. Paerl HW. Mitigating harmful cyanobacterial blooms in a human- and climaticallyimpacted world. Life (Basel). 2014;4(4):988-1012. doi:10.3390/life4040988.

760 39. Wu T, Qin B, Brookes JD, Shi K, Zhu G, Zhu M et al. The influence of changes in wind patterns on the areal extension of surface cyanobacterial blooms in a large shallow lake in China. Science of The Total Environment. 2015;518-519:24-30. doi:https://doi.org/10.1016/j.scitotenv.2015.02.090.

40. Cyanobacteria and cyanotoxins: information for drinking water systems. In: EPA, editor. Washington, DC2014.

41. Sanseverino I, Conduto António DS, Loos R, Lettieri T. Cyanotoxins: methods and approaches for their analysis and detection. Publications Office of the European Union. 2017. doi:http://doi.org/10.2760/630736 (print) http://doi.org/10.2760/36186 (online). 42. Zanchett $\mathrm{G}$, Oliveira-Fino EC. Cyanobacteria and cyanotoxins. from impacts on 2013;5(10):1896-917. doi:http://doi.org/10.3390/toxins5101896.

43. D'Anglada LV, Strong J. Drinking water health advisory for the cyanobacterial toxin cylindrospermopsin. In: EPA US, editor. Washington, DC2015. 

https://www.epa.gov/sites/production/files/2016-05/documents/webinar-understandingcyanobacterial.pdf.

45. Negri AP, Jones GJ. Bioaccumulation of paralytic shellfish poisoning (PSP) toxins from the cyanobacterium Anabaena circinalis by the freshwater mussel Alathyria condola. Toxicon. 1995;33(5):667-78. doi:https://doi.org/10.1016/0041-0101(94)00180-G. 46. Wiese M, D'Agostino PM, Mihali TK, Moffitt MC, Neilan BA. Neurotoxic alkaloids: saxitoxin and its analogs. Mar Drugs. 2010;8(7):2185-211. doi:http://doi.org/10.3390/md8072185.

47. Otten TG, Paerl HW. Health effects of toxic cyanobacteria in U.S. drinking and recreational waters: our current understanding and proposed direction. Curr Environ Health Rep. 2015;2(1):75-84. doi:http://doi.org/10.1007/s40572-014-0041-9. 48. Sivonen K, Jones G. Cyanobacterial toxins. In: Bartram J, editor. Toxic cyanobacteria in water: a guide to their public health consequences, monitoring and management. World Health Organization; 1999.

789 49. Rzymski P, Poniedziałek B. Review paper: Dermatotoxins synthesized by blue-green algae (Cyanobacteria). Advances in Dermatology and Allergology. 2012;29(1):47-50. Tumor Promoters from Marine Natural Products. Marine Toxins. ACS Symposium Series, vol 418: American Chemical Society; 1990. p. 232-40.

794 51. Chen Y, Yu S, Yang JB. Microcystins in drinking water and cancer mortality in a city along Taihu Lake. China Oncology. 2002;12:485-8.

796 52. Guidelines for Drinking-water Quality: forth edition incorporating the first addendum 4th ed. World Health Organization; 2017.

53. D'Anglada LV, Donohue JM, Strong J, Hawkins B. Health effects support document for the cyanobacterial toxin microcystins. In: EPA US, editor. Washington, DC2015.

800 54. NHMRC, NHMMC. Australian drinking water guidelines paper 6 National Water Quality Management Strategy. Canberra: National Health and Medical Research Council, National Resource Management Ministerial Council; 2011.

803 55. Mazur-Marzec H, Sutryk K, Kobos J, Hebel A, Hohlfeld N, Błaszczyk A et al. 804 Occurrence of cyanobacteria and cyanotoxin in the Southern Baltic Proper. Filamentous 805 cyanobacteria versus single-celled picocyanobacteria. Hydrobiologia. 2013;701(1):235-52. doi:http://doi.org/10.1007/s10750-012-1278-7. 56. Volume 1: Coastal and Fresh waters Guidelines for safe recreational water environments. World Health Organization; 2003.

809 57. Rücker J, Stüken A, Nixdorf B, Fastner J, Chorus I, Wiedner C. Concentrations of 810 particulate and dissolved cylindrospermopsin in 21 Aphanizomenon-dominated temperate lakes. Toxicon. 2007;50(6):800-9. doi:https://doi.org/10.1016/j.toxicon.2007.06.019. 58. Saker ML, Eaglesham GK. The accumulation of cylindrospermopsin from the cyanobacterium Cylindrospermopsis raciborskii in tissues of the Redclaw crayfish Cherax quadricarinatus. Toxicon. 1999;37(7):1065-77. doi:https://doi.org/10.1016/S00410101(98)00240-2.

816 59. Humpage AR, Falconer IR. Oral toxicity of the cyanobacterial toxin 817 cylindrospermopsin in male Swiss albino mice: Determination of no observed adverse effect 818 level for deriving a drinking water guideline value. Environ Toxicol. 2003;18(2):94-103. 819 doi:http://doi.org/10.1002/tox.10104.

820 60. Trainer VL, Hardy FJ. Integrative monitoring of marine and freshwater harmful algae in Washington state for public health protection. Toxins (Basel). 2015;7(4):1206-34. doi:http://doi.org/10.3390/toxins7041206. 

in the large lakes south of the Alps: phylogenetic assessment and toxigenic potential. FEMS Microbiol Ecol. 2016;92(10). doi:http://doi.org/10.1093/femsec/fiw155. 62. Ibelings BW, Backer LC, Kardinaal WEA, Chorus I. Current approaches to cyanotoxin risk assessment and risk management around the globe. Harmful Algae. 2015;49:63-74. doi:http://doi.org/10.1016/j.hal.2014.10.002. Wallig MA, editors. Haschek and Rousseaux's Handbook of Toxicologic Pathology (Third Edition). Boston: Academic Press; 2013. p. 1155-86.

64. Lajeunesse A, Segura PA, Gélinas M, Hudon C, Thomas K, Quilliam MA et al. Detection and confirmation of saxitoxin analogues in freshwater benthic Lyngbya wollei algae collected in the St. Lawrence River (Canada) by liquid chromatography-tandem mass $\begin{array}{lllll}\text { spectrometry. } & \mathrm{J} & \text { Chromatogr } & \text { A. } & \text { 2012;1219:93-103. }\end{array}$ doi:https://doi.org/10.1016/j.chroma.2011.10.092.

65. Jüttner F, Watson SB. Biochemical and ecological control of Geosmin and 2Methylisoborneol in source waters. Appl Environ Microbiol. 2007;73(14):4395-406. doi:http://doi.org/10.1128/AEM.02250-06

66. Izaguirre G, Hwang CJ, Krasner SW, McGuire MJ. Geosmin and 2-Methylisoborneol from cyanobacteria in three water supply systems. Appl Environ Microbiol. 1982;43(3):70884214.

843 67. Young WF, Horth H, Crane R, Ogden T, Arnott M. Taste and odour threshold concentrations of potential potable water contaminants. Water res. 1996;30(2):331-40. doi:https://doi.org/10.1016/0043-1354(95)00173-5. 68. Richardson K. Harmful or exceptional phytoplankton blooms in the marine ecosystem. In: Blaxter JHS, Southward AJ, editors. Advances in Marine Biology. Academic Press; 1997. p. 301-85.

69. Kong P, Moorman GW, Lea-Cox JD, Ross DS, Richardson PA, Hong C. Zoosporic tolerance to $\mathrm{pH}$ stress and its implications for Phytophthora species in aquatic ecosystems. Appl Environ Microbiol. 2009;75(13):4307-14. doi:http://doi.org/10.1128/AEM.00119-09 70. Atli G, Canli EG, Eroglu A, Canli M. Characterization of antioxidant system parameters in four freshwater fish species. Ecotox Environ Safe. 2016;126:30-7. doi:https://doi.org/10.1016/j.ecoenv.2015.12.012. 71. Schmetterer G. Cyanobacterial respiration. In: Bryant DA, editor. The Molecular Biology of Cyanobacteria. Dordrecht: Springer Netherlands; 1994. p. 409-35.

72. Sanseverino I, Conduto António DS, Pozzoli L, Dobricic S, Lettieri T. Algal bloom and its economic impact. 2016.

73. Lopez CB, Jewett EB, Dortch Q, Walton BT, Hudnell HK. Scientific assessment of freshwater harmful algal bloom. Washington, DC2008.

74. Pretty JN, Mason CF, Nedwell DB, Hine RE, Leaf S, Dils R. Environmental costs of freshwater eutrophication in England and Wales. Environ Sci Technol. 2003;37(2):201-8. doi:http://doi.org/10.1021/es020793k.

864 75. Dodds WK, Bouska WW, Eitzmann JL, Pilger TJ, Pitts KL, Riley AJ et al. 865 Eutrophication of U.S. freshwaters: analysis of potential economic damages. Environ Sci Technol. 2009;43(1):12-9. doi:http://doi.org/10.1021/es801217q.

76. Kouzminov A, Ruck J, Wood SA. New Zealand risk management approach for toxic cyanobacteria in drinking water. 2007;31(3):275-81. doi:http://doi.org/10.1111/j.1467842X.2007.00061.x.

77. Ibelings BW, Fastner J, Bormans M, Visser PMJAE. Cyanobacterial blooms. Ecology, prevention, mitigation and control: Editorial to a CYANOCOST Special Issue. Aquat Ecol. 2016;50(3):327-31. doi:http://doi.org/10.1007/s10452-016-9595-y. 
78. Schindler DW. Eutrophication and eecovery in experimental lakes: implications for lake management.

Science.

1974; 184(4139):897-9. doi:http://doi.org/10.1126/science.184.4139.897 79. Jeppesen E, Jensen JP, Søndergaard M. Response of phytoplankton, zooplankton, and fish to re-oligotrophication: An 11 year study of 23 Danish lakes. Aquat Ecosyst Health. 2002;5(1):31-43. doi:https://doi.org/10.1080/14634980260199945.

80. Schindler DW, Hecky RE, Findlay DL, Stainton MP, Parker BR, Paterson MJ et al. Eutrophication of lakes cannot be controlled by reducing nitrogen input: Results of a 37-year whole-ecosystem experiment. Proceedings of the National Academy of Sciences. 2008;105(32):11254-8. doi:http://doi.org/10.1073/pnas.0805108105

883 81. Paerl HW, Hall NS, Calandrino ES. Controlling harmful cyanobacterial blooms in a world experiencing anthropogenic and climatic-induced change. Sci Total Environ. 2011;409(10):1739-45. doi:https://doi.org/10.1016/j.scitotenv.2011.02.001. 82. Harke MJ, Gobler CJ. Global transcriptional responses of the toxic cyanobacterium, Microcystis aeruginosa, to nitrogen stress, phosphorus stress, and growth on organic matter. PLOS ONE. 2013;8(7):e69834. doi:http://doi.org/10.1371/journal.pone.0069834. 83. Müller S, Mitrovic SM. Phytoplankton co-limitation by nitrogen and phosphorus in a shallow reservoir: progressing from the phosphorus limitation paradigm. Hydrobiologia. 2015;744(1):255-69. doi:http://doi.org/10.1007/s10750-014-2082-3.

84. Moore BC, Cross BK, Beutel M, Dent S, Preece E, Swanson M. Newman Lake restoration: A case study Part III. Hypolimnetic oxygenation. Lake Reserv Manage. 2012;28(4):311-27. doi:http://doi.org/10.1080/07438141.2012.738463. 85. Toffolon M, Ragazzi M, Righetti M, Teodoru CR, Tubino M, Defrancesco C et al. Effects of artificial hypolimnetic oxygenation in a shallow lake. Part 1: Phenomenological description and management. J Environ Manage. 2013;114:520-9. doi:https://doi.org/10.1016/j.jenvman.2012.10.062.

86. Bormans M, Maršálek B, Jančula DJAE. Controlling internal phosphorus loading in lakes by physical methods to reduce cyanobacterial blooms: a review. 2016;50(3):407-22. doi:https://doi.org/10.1007/s10452-015-9564-x.

902 87. Douglas GB, Adeney JA, Robb M. A novel technique for reducing bioavailable phosphorus in water and sediments International Association Water Quality Conference on Diffuse Pollution1999. p. 517-23.

88. Robb M, Greenop B, Goss Z, Douglas G, Adeney J. Application of PhoslockTM, an innovative phosphorus binding clay, to two Western Australian waterways: preliminary findings. Hydrobiologia. 2003;494(1):237-43. doi:http://doi.org/10.1023/a:1025478618611.

89. Copetti D, Finsterle K, Marziali L, Stefani F, Tartari G, Douglas G et al. Eutrophication management in surface waters using lanthanum modified bentonite: a review. Water res. 2016;97:162-74. doi:https://doi.org/10.1016/j.watres.2015.11.056.

90. Stroom JM, Kardinaal WEA. How to combat cyanobacterial blooms: strategy toward preventive lake restoration and reactive control measures. Aquat Ecol. 2016;50(3):541-76. doi:http://doi.org/10.1007/s10452-016-9593-0.

914 91. Bullerjahn GS, McKay RM, Davis TW, Baker DB, Boyer GL, D'Anglada LV et al. 915 Global solutions to regional problems: collecting global expertise to address the problem of 916 harmful cyanobacterial blooms. A Lake Erie case study. Harmful Algae. 2016;54:223-38. doi:https://doi.org/10.1016/j.hal.2016.01.003.

92. Tátrai I, Mátyás K, Korponai J, Paulovits G, Pomogyi P. The role of the Kis-Balaton water protection system in the control of water quality of Lake Balaton. Ecol Eng. 2000;16(1):73-8. doi:https://doi.org/10.1016/S0925-8574(00)00091-4. 
93. Park J, Church J, Son Y, Kim K-T, Lee WH. Recent advances in ultrasonic treatment:

922 Challenges and field applications for controlling harmful algal blooms (HABs). Ultrason Sonochem. 2017;38:326-34. doi:https://doi.org/10.1016/j.ultsonch.2017.03.003. 94. Rajasekhar P, Fan L, Nguyen T, Roddick FA. A review of the use of sonication to control cyanobacterial blooms. Water res. 2012;46(14):4319-29. doi:https://doi.org/10.1016/j.watres.2012.05.054.

95. Suslick KS. Sonochemistry. Science. 1990;247(4949):1439-45. doi:http://doi.org/10.1126/science.247.4949.1439

96. Schneider OD, Weinrich LA, Brezinski S. Ultrasonic treatment of algae in a New Jersey reservoir. Journal - American Water Works Association. 2015;107(10):E533-E42. doi:http://doi.org/10.5942/jawwa.2015.107.0149.

97. Mishra S, Stumpf RP, Schaeffer BA, Werdell PJ, Loftin KA, Meredith A. Measurement of cyanobacterial bloom magnitude using satellite remote sensing. Scientific Reports. 2019;9(1):18310. doi:http://doi.org/10.1038/s41598-019-54453-y.

98. Bui MH, Pham TL, Dao TS. Prediction of cyanobacterial blooms in the Dau Tieng Reservoir using an artificial neural network. Marine and Freshwater Research. 2017;68(11):2070-80. doi:https://doi.org/10.1071/MF16327.

99. Schaeffer B, Loftin K, Stumpf R, Werdell J. Agencies collaborate, develop a cyanobacteria assessment network. Eos. 2015;96. doi:http://doi.org/10.1029/2015EO038809.

100. Algae. WaterNSW. 2019. https://www.waternsw.com.au/water-quality/algae\#stay.

101. Treatment Options. In: Newcombe G, editor. International guidance manual for the management of toxic cyanobacteria. United Kingdom: Global Water Research Coalition; 2009. 102. Waters T, Dugan A, Lieberman R, Speth T, Carroll G. Water treatment optimization for cyanotoxins. In: EPA, editor. Washington, DC2016.

103. Singh G, Patidar SK. Microalgae harvesting techniques: A review. J Environ Manage. 2018;217:499-508. doi:https://doi.org/10.1016/j.jenvman.2018.04.010.

104. Griffiths MJ, Dicks RG, Richardson C, Harrison ST. Advantages and challenges of microalgae as a source of oil for biodiesel In: Stoytcheva M, Montero G, editors. Biodiesel Feedstocks and Processing Technologies. InTechOpen; 2011.

105. Barros AI, Gonçalves AL, Simões M, Pires JCM. Harvesting techniques applied to microalgae: A review. Renew Sust Energ Rev. 2015;41:1489-500. doi:https://doi.org/10.1016/j.rser.2014.09.037.

106. Fasaei F, Bitter JH, Slegers PM, van Boxtel AJB. Techno-economic evaluation of microalgae harvesting and dewatering systems. Algal Res. 2018;31:347-62. doi:https://doi.org/10.1016/j.algal.2017.11.038.

107. Zaffiro A, Rosenblum L, Wendelken SC. Method 546: Determination of total microcystins and nodularins in drinking water and ambient water by enzyme-linked immunosorbent assay. U.S. EPA; 2015.

108. Gaget V, Lau M, Sendall B, Froscio S, Humpage AR. Cyanotoxins: Which detection technique for an optimum risk assessment? Water res. 2017;118:227-38. doi:https://doi.org/10.1016/j.watres.2017.04.025.

109. Rudi K, Skulberg OM, Skulberg R, Jakobsen KS. Application of sequence-specific labeled 16S rRNA gene oligonucleotide probes for genetic profiling of cyanobacterial abundance and diversity by array hybridization. Appl Environ Microbiol. 2000;66(9):4004-11. doi:http://doi.org/10.1128/aem.66.9.4004-4011.2000.

110. Rantala A, Rizzi E, Castiglioni B, De Bellis G, Sivonen K. Identification of hepatotoxin-producing cyanobacteria by DNA-chip. Environ Microbiol. 2008;10(3):653-64. doi:http://doi.org/10.1111/j.1462-2920.2007.01488.x.

111. EPA. Detection methods for cyanotoxins. 2005. https://www.epa.gov/ground-waterand-drinking-water/detection-methods-cyanotoxins. 
112. Moreira C, Ramos V, Azevedo J, Vasconcelos V. Methods to detect cyanobacteria and

972 their toxins in the environment. Appl Microbiol Biot. 2014;98(19):8073-82.

973

974

975

976

977

978

979

980

981

982

983

984

985

986

987

988

989

990

991

992

993

994

995

996

997

998

999

1000

1001

1002

1003

1004

1005

1006

1007

1008

1009

1010

1011

1012

1013

1014

1015

1016

1017

1018

1019

1020 doi:http://doi.org/10.1007/s00253-014-5951-9.

113. Kamp L, Church JL, Carpino J, Faltin-Mara E, Rubio F. The effects of water sample treatment, preparation, and storage prior to cyanotoxin analysis for cylindrospermopsin, microcystin and saxitoxin. Chem-Biol Interact. 2016;246:45-51. doi:https://doi.org/10.1016/j.cbi.2015.12.016.

114. Gurbuz F, Metcalf JS, Codd GA, Karahan AG. Evaluation of enzyme-linked immunosorbent assays (ELISAs) for the determination of microcystins in cyanobacteria. Environ Forensics. 2012;13(2):105-9. doi:http://doi.org/10.1080/15275922.2012.676596.

115. Aguilar M-I. Reversed-phase high-performance liquid chromatography. In: Aguilar MI, editor. HPLC of Peptides and Proteins: Methods and Protocols. Totowa, NJ: Springer New York; 2004. p. 9-22.

116. Dell'Aversano C, Hess P, Quilliam MA. Hydrophilic interaction liquid chromatography-mass spectrometry for the analysis of paralytic shellfish poisoning (PSP) toxins. $\quad \mathrm{J} \quad$ Chromatogr $\quad$ A. $2005 ; 1081(2): 190-201$. doi:https://doi.org/10.1016/j.chroma.2005.05.056.

117. Chen J, Gao L, Li Z, Wang S, Li J, Cao W et al. Simultaneous screening for lipophilic and hydrophilic toxins in marine harmful algae using a serially coupled reversed-phase and hydrophilic interaction liquid chromatography separation system with high-resolution mass spectrometry. Analytica Chimica Acta. 2016;914:117-26. doi:https://doi.org/10.1016/j.aca.2016.01.062.

118. Newcombe G, Nicholson B. Treatment options for the saxitoxin class of cyanotoxins. Water Supply. 2002;2(5-6):271-5. doi:http://doi.org/10.2166/ws.2002.0179

119. Nimptsch J, Wiegand C, Pflugmacher S. Cyanobacterial toxin elimination via bioaccumulation of MC-LR in aquatic macrophytes: an application of the "Green Liver Concept". Environ Sci Technol. 2008;42(22):8552-7. doi:http://doi.org/10.1021/es8010404.

120. Pflugmacher S, Kühn S, Lee S, Choi J, Baik S, Kwon K et al. Green Liver Systems ${ }^{\circledR}$ for water purification: using the phytoremediation potential of aquatic macrophytes for the removal of different cyanobacterial toxins from water. American Journal of Plant Sciences. 2015;6:1607-18. doi:http://dx.doi.org/10.4236/ajps.2015.69161.

121. Trung B, Dao TS, Faassen E, Lürling M. Cyanobacterial blooms and microcystins in $\begin{array}{llll}\text { Southern } & \text { Vietnam. } & \text { Toxins } & \text { (Basel). }\end{array}$ doi:https://dx.doi.org/10.3390\%2Ftoxins10110471.

122. Dillon JC, Phuc AP, Dubacq JP. Nutritional value of the alga Spirulina. In: Simopoulos AP, editor. Plants in Human Nutrition. Basel: Karger; 1995. p. 32-46.

123. Liang S, Liu X, Chen F, Chen Z. Current microalgal health food R \& D activities in China. In: Ang PO, editor. Asian Pacific Phycology in the 21st Century: Prospects and Challenges. Developments in Hydrobiology. Dordrecht: Springer Netherlands; 2004. p. 45-8.

124. Yamaguchi K. Recent advances in microalgal bioscience in Japan, with special reference to utilization of biomass and metabolites: a review. J Appl Phycol. 1996;8(6):487502. doi:http://doi.org/10.1007/bf02186327.

125. Spolaore P, Joannis-Cassan C, Duran E, Isambert A. Commercial applications of microalgae. J Biosci Bioeng. 2006;101(2):87-96. doi:https://doi.org/10.1263/jbb.101.87.

126. Milledge JJ. Commercial application of microalgae other than as biofuels: a brief review. Rev Environ Sci Biotechnol. 2011;10(1):31-41. doi:http://doi.org/10.1007/s11157010-9214-7.

127. Oren A, Gunde-Cimerman N. Mycosporines and mycosporine-like amino acids: UV protectants or multipurpose secondary metabolites? FEMS Microbiol Lett. 2007;269(1):1-10. doi:http://doi.org/10.1111/j.1574-6968.2007.00650.x 
1021 128. Kageyama H, Waditee-Sirisattha R. Chapter 5 - Mycosporine-like amino acids as 1022 multifunctional secondary metabolites in cyanobacteria: from biochemical to application aspects. In: Atta ur R, editor. Studies in Natural Products Chemistry. Elsevier; 2018. p. 15394.

129. Singh R, Parihar P, Singh M, Bajguz A, Kumar J, Singh S et al. Uncovering potential applications of cyanobacteria and algal metabolites in biology, agriculture and medicine: current status and future prospects. Front Microbiol. 2017;8(515). doi:http://doi.org/10.3389/fmicb.2017.00515.

130. Liu Z, Häder DP, Sommaruga R. Occurrence of mycosporine-like amino acids (MAAs) in the bloom-forming cyanobacterium Microcystis aeruginosa. Journal of Plankton Research. 2004;26(8):963-6. doi:http://doi.org/10.1093/plankt/fbh083

1032 131. Bhatia S, Garg A, Sharma K, Kumar S, Sharma A, Purohit AP. Mycosporine and mycosporine-like amino acids: A paramount tool against ultra violet irradiation. Pharmacogn Rev. 2011;5(10):138-46. doi:https://doi.org/10.4103/0973-7847.91107.

132. Stevenson CS, Capper EA, Roshak AK, Marquez B, Grace K, Gerwick WH et al. Scytonemin-a marine natural product inhibitor of kinases key in hyperproliferative inflammatory diseases. Inflamm 2002;51(2):112-4. doi:http://doi.org/10.1007/bf02684014.

133. Rastogi RP, Sonani RR, Madamwar D. Cyanobacterial sunscreen Scytonemin: role in photoprotection and biomedical Research. Appl Biochem Biotech. 2015;176(6):1551-63. doi:http://doi.org/10.1007/s12010-015-1676-1.

1042 134. De Philippis R, Sili C, Paperi R, Vincenzini M. Exopolysaccharide-producing cyanobacteria and their possible exploitation: A review. J Appl Phycol. 2001;13(4):293-9. doi:http://doi.org/10.1023/A:1017590425924.

135. Okajima MK, Bamba T, Kaneso Y, Hirata K, Fukusaki E, Kajiyama Si et al. Supergiant ampholytic sugar chains with imbalanced charge ratio form saline ultra-absorbent hydrogels. Macromolecules. 2008;41(12):4061-4. doi:http://doi.org/10.1021/ma800307w.

136. Okajima MK, Miyazato S, Kaneko T. Cyanobacterial megamolecule sacran efficiently forms LC gels with very heavy metal ions. Langmuir. 2009;25(15):8526-31. doi:http://doi.org/10.1021/la8036956.

1051 137. Saini DK, Pabbi S, Shukla P. Cyanobacterial pigments: Perspectives and 1052 biotechnological approaches. Food Chem Toxicol. 2018;120:616-24. doi:https://doi.org/10.1016/j.fct.2018.08.002.

138. Pabbi S. Blue green algae: a potential biofertilizer for rice. In: Sahoo D, Seckbach J, editors. The Algae World. Dordrecht: Springer Netherlands; 2015. p. 449-65.

139. Singh JS, Kumar A, Rai AN, Singh DP. Cyanobacteria: a precious bio-resource in agriculture, ecosystem, and environmental sustainability. 2016;7(529). doi:http://doi.org/10.3389/fmicb.2016.00529.

1060 Ohyama T, editor. Advances in Biology and Ecology of Nitrogen Fixation. InTechOpen; 2014. 1061 p. 23-48.

1062 141. Rai AK, Sharma NK. Phosphate metabolism in the cyanobacterium Anabaena doliolum 1063 under salt stress. Curr Microbiol. 2006;52(1):6-12. doi:http://doi.org/10.1007/s00284-0050043-9.

142. Ghazal FM, Mahdy E-SM, EL- Fattah MSA, EL-Sadany AEGY, Doha NME. The use of cyanobacteria as biofertilizer in wheat cultivation under different nitrogen rates. Nature and Science 2018;16(4):30-5. doi:http://doi.org/10.7537/marsnsj160418.06.

1070

143. Gebre E, Abdi T, Wolde-meskel E, Bulta A, Davis J. Response of kale (Brassica Oleracea L) crop to cyanobacterial biofertilizer in Ziway area, Ethiopia. Journal of Biology, Agriculture and Healthcare 2018;8(13). 
144. Grzesik M, Romanowska-Duda Z, Kalaji HM. Effectiveness of cyanobacteria and green algae in enhancing the photosynthetic performance and growth of willow (Salix viminalis L.) plants under limited synthetic fertilizers application. Photosynthetica 2017;55(3):510-21. doi:http://doi.org/10.1007/s11099-017-0716-1.

145. Sarsekeyeva F, Zayadan BK, Usserbaeva A, Bedbenov VS, Sinetova MA, Los DA.

1076 Cyanofuels: biofuels from cyanobacteria. Reality and perspectives. Photosynth Res. 2015;125(1):329-40. doi:http://doi.org/10.1007/s11120-015-0103-3.

1079 146. Savakis P, Hellingwerf KJ. Engineering cyanobacteria for direct biofuel production from CO2. Curr Opin doi:https://doi.org/10.1016/j.copbio.2014.09.007.

147. Singh V, Chaudhary DK, Mani I, Dhar PK. Recent advances and challenges of the use of cyanobacteria towards the production of biofuels. Renew Sust Energ Rev. 2016;60:1-10. doi:https://doi.org/10.1016/j.rser.2016.01.099.

148. Deng M-D, Coleman JR. Ethanol synthesis by genetic engineering in cyanobacteria. Appl Environ Microbiol. 1999;65(2):523.

149. Sveshnikov DA, Sveshnikova NV, Rao KK, Hall DO. Hydrogen metabolism of mutant forms of Anabaena variabilis in continuous cultures and under nutritional stress. FEMS Microbiol Lett. 1997;147(2):297-301. doi:http://doi.org/10.1111/j.1574-6968.1997.tb10257.x 150. Ali I, Basit MA. Significance of hydrogen content in fuel combustion. Int J Hydrogen Energ. 1993;18(12):1009-11. doi:https://doi.org/10.1016/0360-3199(93)90083-M.

151. Srirangan K, Pyne ME, Perry Chou C. Biochemical and genetic engineering strategies to enhance hydrogen production in photosynthetic algae and cyanobacteria. Bioresource Technol. 2011;102(18):8589-604. doi:https://doi.org/10.1016/j.biortech.2011.03.087.

152. Cournac L, Guedeney G, Peltier G, Vignais PM. Sustained photoevolution of molecular hydrogen in a mutant of Synechocystis sp. strain PCC 6803 deficient in the type I NADPH$\begin{array}{llll}\text { dehydrogenase } & \text { complex. } & \mathrm{J} & \text { Bacteriol. }\end{array}$ doi:http://doi.org/10.1128/JB.186.6.1737-1746.2003. production activity of a Nostoc sp. PCC 7422 uptake hydrogenase-deficient mutant with high nitrogenase activity. Mar Biotechnol. 2007;9(1):101-12. doi:http://doi.org/10.1007/s10126006-6035-3.

$1102 \quad$ 154. Mona S, Kaushik A, Kaushik CP. Hydrogen production and metal-dye bioremoval by 1103 a Nostoc linckia strain isolated from textile mill oxidation pond. Bioresource Technol. a Nostoc linckia strain isolated from textile mill oxidation pond. Bio 155. Boopathi T, Ki J-S. Impact of environmental factors on the regulation of cyanotoxin production. Toxins (Basel). 2014;6(7):1951-78. doi:https://doi.org/10.3390/toxins6071951. 156. Alexova R, Haynes PA, Ferrari BC, Neilan BA. Comparative protein expression in different strains of the bloom-forming cyanobacterium Microcystis aeruginosa. Mol Cell Proteomics. 2011;10(9):M110.003749. doi:http://doi.org/10.1074/mcp.M110.003749.

157. Camargo S, Valladares A, Flores E, Herrero A. Transcription activation by NtcA in the absence of consensus NtcA-binding sites in an anabaena heterocyst differentiation gene promoter. J Bacteriol. 2012;194(11):2939-48. doi:https://doi.org/10.1128/JB.05994-11.

158. Burford MA, Davis TW, Orr PT, Sinha R, Willis A, Neilan BA. Nutrient-related changes in the toxicity of field blooms of the cyanobacterium, Cylindrospermopsis raciborskii. 2014;89(1):135-48. doi:https://doi.org/10.1111/1574-6941.12341.

159. Tsuchiya S, Cho Y, Konoki K, Nagasawa K, Oshima Y, Yotsu-Yamashita M. Synthesis and identification of proposed biosynthetic intermediates of saxitoxin in the cyanobacterium Anabaena circinalis (TA04) and the dinoflagellate Alexandrium tamarense (Axat-2). Org Biomol Chem. 2014;12(19):3016-20. doi:http://doi.org/10.1039/C4OB00071D. 
